\title{
Influence of an oxygen minimum zone and macroalgal enrichment on benthic megafaunal community composition in a NE Pacific submarine canyon
}

\author{
Domke Lia ${ }^{1,{ }^{*}}$, Lacharite Myriam ${ }^{1,3}$, Metaxas Anna ${ }^{1}$, Matabos Marjolaine ${ }^{2}$ \\ ${ }^{1}$ Dalhousie Univ, Dept Oceanog, Halifax, NS, Canada. \\ ${ }^{2}$ IFREMER, REM EEP, Ctr Bretagne, Lab Environm Profond, Plouzane, France. \\ ${ }^{3}$ Nova Scotia Community Coll, NSCC Appl Oceans Res, Dartmouth, NS, Canada. \\ *Corresponding author : Lia Domke, email address : liakatherine9@gmail.com
}

\begin{abstract}
:
Megafaunal diversity in the deep sea shows a parabolic pattern with depth. It can be affected by factors such as low oxygen concentration, which suppresses diversity, or the presence of submarine canyons, which enhances it. Barkley Canyon, located off the west coast of British Columbia, Canada, is a submarine canyon that extends from the continental margin $(200 \mathrm{~m})$ into the deep ocean $(2,000 \mathrm{~m})$. This canyon receives drift kelp from shoreline kelp forests and contains an oxygen minimum zone (OMZ) at 500 to $1,500 \mathrm{~m}$ depth. Our study investigated the abundance and diversity of epibenthic megafauna over a range of depths $(200-2,000 \mathrm{~m})$ and oxygen concentrations $(0.5-5.0 \mathrm{ml} / \mathrm{L})$ within Barkley Canyon, as well as changes in abundance near detrital kelp. Video was collected using the remotely operated vehicle ROPOS along seven 1-km cross-canyon (i.e., across the axis of the canyon) transects and three 40-m perpendicular cross-transects over kelp. Taxonomic groups were associated with depth, temperature, and the presence of pebbles. The OMZ restricted pennatulids, and edge effects along OMZ boundaries were observed for ophiuroids. The geomorphology of the sea floor affected the distribution of taxa across the canyon, with Porifera mainly found along the walls and Echinoidea within the canyon axis. Expected richness exhibited a bimodal pattern, peaking at 300 and $2,000 \mathrm{~m}$, possibly due to the combined effect of the $\mathrm{OMZ}$ and the submarine canyon. Echinoidea aggregated near drift kelp at 200 and $300 \mathrm{~m}$. We found that faunal communities in Barkley Canyon were influenced by several confounded factors including depth, oxygen and substrate. Understanding faunal patterns is paramount with increased exploitation and a changing climate.
\end{abstract}

Keywords : Barkley Canyon, benthic surveys, British Columbia, kelp detritus, oxygen minimum zone, submarine canyon 


\section{Introduction}

Submarine canyons are steep-walled valleys cutting into continental margins.

75 Over 9,000 canyons have been currently identified worldwide with 2,000 in the North

76 Pacific Ocean (Harris et al. 2014). Canyons can be a source of habitat heterogeneity in

77 the deep sea, resulting from fluctuating physical processes (Puig et al. 2014; Callow et

78 al., 2014), food availability (Vetter, 1994; Harrold et al. 1998; Vetter \& Dayton 1999),

79 and/or oxygen levels (Levin 2003).

80 Physical processes, such as internal waves, turbidity currents, and upwelling and

81 downwelling can be enhanced in canyons compared to the adjacent continental slope

82 (Callow et al. 2014) and can alter the canyon habitat through funneling sediment and

83 organic detritus from the shelf (Harrold et al. 1998; Vetter \& Dayton 1998; Vetter \&

84 Dayton 1999; Puig et al. 2014), erosion, or sediment re-suspension (reviewed in Callow

85 et al. 2014). Increased input of organic detritus from the shelf can enhance benthic

86 organic matter to a food-limited environment (Harrold et al. 1998; Vetter \& Dayton 1998;

87 Vetter \& Dayton 1999).

88 In general, on the continental slope, faunal abundance and biomass decrease with

89 depth from the shelf break $(200 \mathrm{~m})$ to the abyssal plains $(4000 \mathrm{~m})$ as a result of the

90 exponential decrease in phytodetrital input from surface waters (Rex et al. 2006). Other

91 factors that can regulate the slope benthic community include oxygen concentration

92 (Gooday et al. 2010) and topography (McClain \& Barry 2010). Submarine canyons 
93 typically exhibit increased biomass and biodiversity relative to non-canyon habitats at

94 similar depths (Vetter \& Dayton 1999; De Leo et al. 2010; McClain \& Barry 2010; Vetter

95 et al. 2010). In canyons, different types of substrates and the presence of exposed

96 bedrock can support high species diversity, with deposit feeders and scavengers

97 exploiting soft-sedimented areas and sessile filter feeders utilizing hard substrate along

98 the canyon walls (Vetter \& Dayton 1998, Huvenne et al. 2011). Amaro et al. (2016)

99 proposed that cliff habitats in Whittard Canyon, Northeast Atlantic, hosted high

100 megafauna diversity because of enhanced food availability for filter feeders and reduced

101 sedimentation. Similarly, in Monterey Canyon, California, influx of organic debris was

102 greater, and megafaunal density higher, on the face of the cliff than at a distance from the

103 cliff (McClain \& Barry 2010).

104 Fluctuations in oxygen level, such as at Oxygen Minimum Zones (OMZs), can

105 also increase habitat heterogeneity along the continental margin (Levin 2003). An OMZ

106 is a region with stable low oxygen, where oxygen concentration drops below $0.5 \mathrm{ml} \mathrm{L}^{-1}$

107 (Levin 2003). OMZs impinge on continental margins at intermediate depths between 100

108 and $1400 \mathrm{~m}$ and occur in areas of high surface productivity (Levin et al. 2001). These

109 low-oxygen areas are sporadic in the deep sea, where oxygen is usually saturated at 5-6

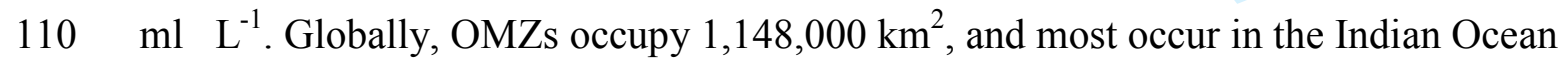

111 (59\%) and the eastern Pacific Ocean (31\%) (Helly \& Levin 2004). OMZs are generated

112 where organic material sinks and is then degraded through aerobic processes, leading to a

113 reduction in oxygen concentration. Weak water circulation and oxygen-depleted source

114 waters enhance OMZs, and variability in productivity and circulation affects the

115 thickness and magnitude of the OMZ (Helly \& Levin 2004). Given the projected increase 
116 in sea surface temperature leading to enhanced ocean stratification, OMZs are predicted

117 to increase in size and intensity in the future (Helly \& Levin 2004; Diaz \& Rosenberg

118 2008).

119 Low oxygen influences the abundance and composition of epibenthic

120 communities in the deep sea. For example, the density of meiofauna increases in

121 OMZs, while both macrofauna and meiofauna exhibit low species richness and

122 dominance of particular taxa (Levin \& Gage 1998; Levin et al. 2001). Density and

123 diversity of megafauna decreases within the core of the OMZ, likely because of low

124 tolerance and lack of adaptation to low oxygen. In the sediments in OMZs, oxygen levels

125 below $0.05 \mathrm{ml} \mathrm{L}^{-1}$ were associated with increased concentrations of phytodetritus and

126 organic matter, as well as preservation of organic material (Cowie \& Hedges 1992; Levin

127 2003; Gooday et al. 2010). However, this rich food source is not always readily available

128 for megafauna that are unable to adapt to the low oxygen levels. Megafaunal densities

129 can be higher along the upper and lower boundaries of the OMZ than within it, likely

130 because of an interaction between the release from low oxygen and the presence of high

131 organic matter (Levin 2003).

132 In the eastern Pacific Ocean, along the west coast of Canada and the United

133 States, OMZs are maintained by upwelling which leads to high productivity and the

134 presence of older, oxygen-poor source water with low rates of replenishment (Wyrtky

135 1966; Reid \& Mantyla 1978). An OMZ is found along the Northeastern Pacific,

136 impinging on submarine canyons. Seasonal variability in the direction of currents

137 influences patterns in upwelling in the area. In winter, the sea surface current runs

138 northwest, parallel to the shore and towards Alaska. In April and May, the current, forced 
139 by a seasonal change in wind, reverses direction to the southeast towards California

140 (Freeland et al. 1984), causing upwelling on the continental margin along the coast of

141 Vancouver Island throughout the summer into early fall (Allen et al. 2001). Upwelling

142 brings nutrients to the surface, increases productivity, and ultimately contributes to the

143 formation of an OMZ (Freeland et al. 1984). A number of studies have noted an increase

144 in upwelling intensity and severity and the number of hypoxic events, resulting in long-

145 term decreasing dissolved oxygen concentrations in the area (Bograd et al. 2008;

146 Whitney et al. 2007).

147 Barkley Canyon is a submarine canyon found within the area affected by the

$148 \mathrm{OMZ}$ in the Northeastern Pacific Ocean. In addition to the influence of the OMZ, the

149 proximity of the canyon to the coast $(\sim 100 \mathrm{~km})$ could affect food supply due to a

150 potential influx of kelp macrodetritus from near coastal kelp forests (Vetter 1994; Harrold

151 et al. 1998). We hypothesized that the canyon will display a low diversity and abundance

152 of megafauna within the OMZ compared to the upper continental slope but that

153 phytodetritus deposits will locally enhance abundance of species adapted to low oxygen

154 concentrations. The combination of these two processes may result in an unusual spatial

155 pattern in abundance and diversity with depth. In this study: 1) we quantified broad-scale

156 patterns in epibenthic megafauna (organisms visible in still images, usually $>1$ to $2 \mathrm{~cm}$ )

157 in relation to depth (200 $\mathrm{m}$ to $2000 \mathrm{~m})$ and oxygen concentration $\left(0.5-5 \mathrm{ml} \mathrm{L}^{-1}\right)$

158 throughout Barkley Canyon; and 2) based on the hypothesis of enhanced organic detritus

159 in submarine canyons, we investigated fine-scale spatial changes in mobile epibenthic

160 megafauna in the presence of macroalgal detritus in Barkley Canyon. 


\section{2. Materials and Methods}

162 2.1 Study area

163 Barkley Canyon is a submarine canyon along the Northeast Pacific continental

164 margin $\sim 100 \mathrm{~km}$ from the west coast of Vancouver Island, British Columbia, Canada

165 (Fig. 1). The canyon is located along the edge of the Cascadia subduction zone, with the

166 head at the continental break and extending into the continental slope from $200 \mathrm{~m}$ to

$167>2000 \mathrm{~m}$ depth. The canyon is $\sim 42 \mathrm{~km}$ long along its longitudinal axis, and its width is

168 narrower at the head $(\sim 1 \mathrm{~km})$ widening to a maximum of $7 \mathrm{~km}$ at the continental slope.

169 The continental margin off the coast of Vancouver Island that includes Barkley Canyon is

170 located in the North Pacific oxygen minimum zone (OMZ) characterized by oxygen

171 concentrations below $0.5 \mathrm{ml} \mathrm{L}^{-1}$ ( Levin 2003; Juniper et al. 2013).

$172 \quad 2.2$ Benthic video surveys

173 We conducted benthic video surveys using the remotely-operated vehicle (ROV)

174 ROPOS aboard the $R / V$ Falkor (Schmidt Ocean Institute) on 4-19 September 2013.

175 ROPOS was equipped with forward-facing and downward-facing high-definition cameras

176 (Insite Pacific Zeus-Plus 1090i HD and Insite Pacific Mini Zeus 1080i HD, respectively)

177 and each camera was equipped with lasers calibrated at $10 \mathrm{~cm}$ apart. The ROV

178 performed $71-\mathrm{km}$ transects approximately along isobaths at different target depths

179 within Barkley Canyon (200 to $2000 \mathrm{~m}$ ), surveying a total of $6906 \mathrm{~m}$ of the seafloor (Fig.

180 1, Table 1). The ROV maintained an altitude of $\sim 1 \mathrm{~m}$ above the seafloor during

181 transects, and is equipped with an ultra-short baseline responder (USBL) allowing its

182 precise positioning on the seafloor. 
Where drift kelp was observed on the seafloor, we conducted 2 perpendicular

184 cross $40-\mathrm{m}$ transects with the kelp debris at the centre (Table 2). After the 2 transects

185 were completed, the kelp debris was collected and blade length measured onboard ship.

186 Kelp were frozen and subsequently weighed in the laboratory. Transects that were longer

187 than $40 \mathrm{~m}$ were shortened to $40 \mathrm{~m}$ (e.g. 200-m transect).

$188 \quad 2.3$ Environmental Data

189 ROPOS was equipped with a CTD profiler (SBE 19plusV2) that recorded oxygen,

190 temperature, and salinity continuously throughout the dive. Based on the CTD data, we

191 identified the location of the oxygen minimum zone, as the depths over which oxygen

192 was below $0.5 \mathrm{ml} \mathrm{L}^{-1}$.

1932.4 Video data processing

194 For each 1-km transect, frame-grabs were extracted from the video of the

195 downward-facing camera at 1-minute intervals (average distance between adjacent

196 frame-grabs: $8 \pm 1 \mathrm{~m}$ ). Images were discarded if they were blurry, if the ROV was too

197 high off the seafloor to distinguish organisms, or if there were other obstructions, such as

198 large fish. Each image was cropped to cover an area of $1 \mathrm{~m} \times 1 \mathrm{~m}$, centered at the

199 brightest portion of the image. Since the ROV was in constant motion, its angle varied

200 between transects and the illuminated area would shift with different frame-grabs. If the

201 image surface area was $<1 \mathrm{~m}^{2}$, the surface area of the maximum height and width in the

202 lit portion of the image was used (range $0.31-1.01 \mathrm{~m}^{2} ; 125$ images $<1 \mathrm{~m}^{2}$ ). In total, 971

203 images were extracted and 860 used for analysis (Table 1). For each 40-m cross transect,

204 the entire video sequence along each segment was analyzed. 
All epibenthic megafauna were enumerated in each image. For the 1-km transects,

206 individuals were included if more than half of their body was within the image or, in the

207 case of sessile species, if the holdfast was in the frame. For the cross transects, all mobile

208 epibenthic megafauna were enumerated along the video transects and their position

209 relative to the kelp detritus recorded. All organisms were identified to the lowest

210 taxonomic level possible based on the images (physical samples unavailable for most

211 species). Since some species could not be identified without specimens (not collected),

212 the term 'morphospecies' is used in this study. Morphospecies were pooled into broader

213 taxonomic groups for the analyses (Alcyonacea, Echinoidea, Porifera, Gastropoda,

214 Crinoidea, Ophiuroidea, Pennatulacea, Hydrozoa, Actiniaria, Decapoda, Holothuroidea,

215 and Asteroidea).

216 Along each 1-km transect, qualitative observations of the substrate type were

217 made. The presence of large boulders or cobbles was recorded, as well as the appearance

218 of the sediment, for example, whether it was easily-disturbed clay, coarser grain sediment

219 or a heavily pebbled area. At the head of the canyon (transects at target depths 200-

$220600 \mathbf{~ m}$ ), we distinguished the walls and axis of the canyon based on the rate of

221 change in depth with horizontal distance throughout the entire1-km transect. For

222 example, at target depths $>600 \mathrm{~m}$, depth only varied by on average $100 \mathrm{~m}$ along the

223 1-km transect with the least variation at the $200 \mathrm{~m}$ target depth $(30 \mathrm{~m}$ over $1 \mathrm{~km})$

224 and the most at $600 \mathrm{~m}$ target depth (130 $\mathrm{m}$ over $1 \mathrm{~km})$.

$225 \quad 2.5$ Data analysis

226 Although there was some depth overlap at the shallower transects (target

227 depths: $\mathbf{2 0 0} \mathbf{~ m , ~} \mathbf{3 0 0} \mathbf{~ m , ~} \mathbf{4 0 0}$ m), the main objective of the study was to sample 
228 megafaunal communities along the axis of the canyon at different "target" depths.

229 Some depth variation is expected given the geomorphology of submarine canyons:

230 walls are typically at shallower depths than the floor. We did not sub-sample

231 transects horizontally since the main feature of interest (the OMZ) is vertically

232 stratified, and this gradient occurs at a broader scale than the overlap in depth

233 range at the shallower transects. The depth variation within transects is much

234 smaller than the depth variation between transects, particularly at depths $>400$

235 m. In the interpretation of our results, we focus mainly on differences in patterns

236 among shallow, intermediate and deep depths and less on individual transects.

237 To show bathymetric patterns in megafaunal abundance throughout the canyon

238 along the OMZ gradient, mean abundance along 1-km transects was calculated from all

239 usable frames by dividing the total number of individuals observed with the total surface

240 area analyzed. Diversity was calculated for each 1-km transect using diversity indices

241 [morphospecies richness (S), Pielou's evenness ( $\left.J^{\prime}\right)$, and Shannon-Weaver's diversity

242 index $\left.\left(H^{\prime}\right)\right]$ and individual-based rarefaction analysis. All individuals in each transect

243 were pooled, yielding a single assemblage per transect. As the diversity indices can be

244 affected by sampling effort, an individual-based rarefaction index was calculated for each

245 transect (Hurlbert 1971). This was calculated by randomly re-sampling individuals for a

246 given sample size to create an expected morphospecies richness. The expected richness

247 for a normalized sample size allows comparisons among transects with a different

248 number of individuals. Expected morphospecies richness was calculated at the second

249 lowest number of individuals $(n=50)$, as well as double this sample size $(n=100)$, to

250 exhibit changes in richness with a small and large normalized sample size. The 800-m 
251 transect was excluded from diversity analysis because too few individuals were observed

$252(\mathrm{n}=51)$ to provide sufficient data to display patterns in expected richness.

253 Correlations between faunal composition and environmental variables were

254 investigated using a redundancy canonical analysis (RDA) which combines aspects of

255 ordination and regression. Environmental factors included depth, concentration of

256 dissolved oxygen and temperature averaged along the transect, as well as substrate type

257 (pebbles vs soft sediment). Prior to analyses, abundance was Hellinger-transformed to

258 mitigate the weight given to species with low counts and 0 data, while being

259 appropriate in Euclidean method-based analyses (Legendre \& Gallagher 2001). A

260 forward selection of the environmental variables was first conducted to select a

261 parsimonious model. The canonical relationship and the individual canonical axes were

262 then tested using the maximum number of possible random permutations, given the

263 relative number of variables and sites. Analyses were performed at the group and

264 morphospecies levels.

265 All analyses were performed in the R environment using the 'vegan' package

266 (Oksanen et al. 2015).

267 3. Results

2683.1 Environmental data

269 Oxygen levels at the sea surface were approximately $5.0 \mathrm{ml} \mathrm{L}^{-1}$, and decreased at

270 the thermocline $\left(\sim 10\right.$ to $50 \mathrm{~m}$ depth) to $\sim 2.0 \mathrm{ml} \mathrm{L}^{-1}$. The oxygen minimum zone (OMZ)

271 was relatively consistent among transects, occurring at intermediate depths, and

272 extending from $\sim 530$ to $\sim 1450 \mathrm{~m}$. Within the OMZ, oxygen concentration declined to a

273 minimum of $0.159 \mathrm{ml} \mathrm{L}^{-1}$ at a depth of approximately $900 \mathrm{~m}$ (Fig. 2). Variability in 
274 oxygen concentration and temperature values were minimal within transects. For

275 example variation at 400, 600, and $2000 \mathrm{~m}$ (average \pm SD) was minimal (respectively

276 oxygen: $1.03 \pm 0.09 \mathrm{ml} \mathrm{L}^{-1}, 0.53 \pm 0.1 \mathrm{ml} \mathrm{L}^{-1}, 1.03 \pm 0.04 \mathrm{ml} \mathrm{L}^{-1}$; temperature: $6.32 \pm$

$\left.277 \quad 0.28{ }^{\circ} \mathrm{C}, 5.2 \pm 0.2^{\circ} \mathrm{C}, 2.1 \pm 0.8^{\circ} \mathrm{C}\right)$.

278 Substrate varied across depths from pebble-dominated sediment in the shallow

279 transects (200 to $400 \mathrm{~m}$ ) to soft muddy sediment in the intermediate to deep transects

280 (600 to $2000 \mathrm{~m}$ ) (Table 3; Fig. 3). At 200 m, cobbles and boulders were common, but

281 became increasingly rare with depth and were rarely seen at depths below $400 \mathrm{~m}$. At

282 depths $>600 \mathrm{~m}$, the substrate was mostly fine to very fine grain sediment (i.e. clay) and

283 was easily disturbed. Bioturbation, mainly tracks, but also burrows and sediment

284 displacement by fish, was common in the deeper transects, in particular within the OMZ

285 core (600- and 800-m transects).

2863.2 Abundance and community composition

287 Epibenthic megafaunal distribution appeared related to depth and oxygen

288 concentration for most taxonomic groups (Fig. 4). Echinoidea were only present in the

289 shallower depths (200 to $400 \mathrm{~m}$ ), whereas Porifera, Gastropoda, and Crinoidea extended

290 into the mid depths of the canyon (200 to $800 \mathrm{~m}$ ). Pennatulacea and hydrozoans were

291 absent from the hypoxic transects $(600$ and $800 \mathrm{~m})$, although they were present shallower

292 and deeper (Fig. 4). Alcyonacea were only present in the deepest transect (2000 m).

293 Actinaria, Decapoda, Holothuroidea, and Asteroidea were present throughout the canyon.

294 At a lower taxonomic level, all groups exhibited depth- and/or oxygen-related

295 distribution patterns. Three taxonomic groups only included a single morphospecies (i.e.

296 Crinoidea, Echinoidea and Gastropoda), while other groups included multiple 
297 morphospecies with different depth distributions (Table A.1). For example, 2 large

298 species of decapods (Munida sp. and Pandalus platyceros) were present at 200 and 300

299 m, whereas only a small decapod (Family Pandalidae) was present at the deeper transects.

300 Similarly for Holothuroidea, Parastichopus leukothele was only present at 200 to $400 \mathrm{~m}$,

301 whereas different taxa were present at depths $>800 \mathrm{~m}$ (Table A.1). For Pennatulacea,

302 Sessiflorae sp. 1 was present at 200, 300, 400, and $2000 \mathrm{~m}$, while a different

303 morhospecies, Sessiflorae sp. 2, was only present at 1500 and $2000 \mathrm{~m}$.

304 Redundancy analysis (RDA) showed that, after forward selection, assemblages

305 (based on taxonomic groups) were significantly correlated to depth, temperature and,

306 marginally, to the presence of pebbles $\left(\mathrm{R}^{2}\right.$ adj $=0.49, p=0.007$, Fig. 5). Only the first

307 canonical axis was significant and explained $45.2 \%$ of the total variation in abundance $(p$

$308=0.04$ ). This axis separated the warmer shallow sites (from 200 to $600 \mathrm{~m}$ ) from the deep

309 colder ones (1500 and $2000 \mathrm{~m}$ ). The presence of Porifera, hydrozoans and echinoids

310 characterized the shallow rocky (i.e. pebbles) sites, while ophiuroids and pennatulaceans

311 were associated with the deep site. Even though neither the second axis nor the oxygen

312 concentration explained a significant amount of the variation in the assemblages, it is

313 noteworthy that the second canonical axis actually separated oxygenated sites from those

314 located inside the OMZ (i.e. 600 and $800 \mathrm{~m}$ ). Additional samples within the OMZ and

315 outside of the $\mathrm{OMZ}$ at similar depths are needed to verify and test this pattern. Similar

316 patterns were observed in analyses using morphospecies, but the canonical relationship

317 was weaker with the model explaining only $29 \%$ of the total variance. However, results

318 using morphospecies must be treated with caution as the species matrix was zero-inflated

319 (75\% of data). 


\subsection{Faunal patterns across the submarine canyon}

321 At the shallower depths of Barkley Canyon (200 to $600 \mathrm{~m}$ ), bathymetry varied

322 along each 1-km transect across the width of the canyon (Fig. 6). Some taxonomic groups

323 exhibited distributions related to the cross-canyon geomorphology of the seafloor along

324 these transects. Porifera were found on the walls of the canyon at all 4 depths (Fig. 6). At

325200,300 , and $400 \mathrm{~m}$, in particular, abundance was greater along the northwest wall than

326 the southeast wall of the canyon (Fig. 6). At $600 \mathrm{~m}$, Porifera were only present on the

327 southeast wall. In contrast, echinoids were present mainly at the axis of the canyon,

328 particularly at 200 and $300 \mathrm{~m}$ (Fig. 6). Munida sp. and P. platyceros were present along

329 the northwest wall at $200 \mathrm{~m}$. At $300 \mathrm{~m}$, Munida sp. and Family Pandalidae were present

330 along the northwest wall, but at $600 \mathrm{~m}$, Family Pandalidae was present throughout the

331 transect (albeit at a much lower abundance), while the Munida sp. and P. platyceros were

332 absent (Fig. 6).

3333.4 Patterns in diversity

334 The greatest megafaunal richness was recorded at $300 \mathrm{~m}$ and $2000 \mathrm{~m}$ and the

335 lowest at $400 \mathrm{~m}$ and $800 \mathrm{~m}$ (Fig. 7b). Richness ranged from 9 morphospecies at $800 \mathrm{~m}$ to

33616 morphospecies at $2000 \mathrm{~m}$, but showed no bathymetric trend (Fig. 7b). Similarly, there

337 was no clear bathymetric pattern in the Shannon-Weaver diversity index or Pielou's

338 evennness but transects with the lowest diversity (200 $\mathrm{m}$ and $1500 \mathrm{~m}$ ) also showed the

339 lowest evenness (Fig. 7c). Expected richness showed a bimodal trend with richness

340 peaking at 300 and $2000 \mathrm{~m}$ (Fig. $7 \mathrm{~d}$ ). 
3413.5 Species aggregations in response to macrodetritus

342 Drift kelp was found along 3 transects at 200, 300, and $1500 \mathrm{~m}$ depth, with the

343 largest piece at $300 \mathrm{~m}$ (Table 4). At $200 \mathrm{~m}$, echinoids aggregated on the drift kelp, with 3

344 individuals found on the kelp itself (Fig. 8), while at $300 \mathrm{~m}$, larger aggregations (20 to 30

345 individuals) were observed (Fig. 8). At $1500 \mathrm{~m}$, there were no aggregations of mobile

346 megafauna on the kelp, however, ophiuroids and holothuroids were present in high

347 abundances along the 40-m transects (Fig. 8). Echinoidea aggregated at 200 and $300 \mathrm{~m}$,

348 but were not present at the deeper 1500-m transects. Although not targeted during

349 sampling, an aggregation of the gastropod Fusitriton oregonensis of 34 individuals $\mathrm{m}^{-2}$

350 was also observed on a carcass of a fish at $174 \mathrm{~m}$ depth (Fig. 9). 


\section{4. Discussion}

3524.1 Bathymetric zonation in abundance

353 Megafauna show distinct zonation along the upper, mid, and lower canyon. The

354 redundancy canonical analysis (RDA) indicated that the abundance of taxonomic groups

355 was significantly correlated with depth, temperature and the presence of pebbles.

356 However, because both temperature and the presence of pebbles varied with depth,

357 the individual effects of each factor are confounded. Porifera, hydrozoan, and

358 echinoids were associated with the shallow rocky sites (200-600 m). Crinoids and

359 gastropods were also found only within the shallow-mid region of the canyon. Porifera

360 and crinoids are both filter feeders and require strong flow to obtain nutrients and hard

361 substrata for attachment (Vogel 1977). The substrate composition (coarse grain sediment:

362 pebbles, cobbles, and boulders) indicates that flow was higher in the shallower region of

363 the canyon. Alternatively, disturbances, such as sediment slumps and turbidity currents,

364 which can be common in canyons, may also restrict the distribution of sessile filter

365 feeders (Inman et al. 1976; Vetter et al. 2010; reviewed in Puig et al. 2014). In Gioia

366 canyon, Pierdomenico et al. (2016) found that the highly active canyon head (turbidity

367 flows and high sedimentation) was relatively devoid of megafauna except for a robust

368 species of sea pens.

369 Some species were only found at the shallow and mid depths of the canyon.

370 The gastropod Fusitriton oregonesis has been recorded from the intertidal zone to 2300

371 m (Smith 1970). However, in our study, this species was only found in the mid-canyon

372 including the $\mathrm{OMZ}$, but not deeper, indicating that factors other than depth or oxygen,

373 such as presence of food or larvae distribution, may be limiting its distribution. $\boldsymbol{F}$.

374 oregonesis is a carnivore feeding on other mollusks, but we observed aggregations 
375 on fish carcasses. It is thus possible that it could be exploiting food sources

376 concentrated within the narrow margins of the canyon. The echinoid

377 Stronglocentrotus fragilis was found only at shallow depths $<400 \mathrm{~m}$, above the OMZ,

378 despite unpublished records of occurrence at $800 \mathrm{~m}$ within Barkley Canyon (Chauvet,

379 unpublished data). S. fragilis has a depth distribution from $30 \mathrm{~m}$ to $>2000 \mathrm{~m}$ (Schultz).

380 However, depths below the OMZ fall outside those where they are most abundant (0-600

381 m) (Duffy et al. 2014; Schultz 2015). In addition, along the Southern Californian

382 Bright, $S$. fragilis have experienced a habitat expansion into shallower slope waters

383 from deep-water environments with increased densities along the upper continental

384 shelf (above $500 \mathrm{~m}$ ) between 2003-2013 (Sato et al. 2017) indicating that $S$. fragilis

385 may become increasingly more common in shallower shelf waters, such as Barkley

386 Canyon. Alternatively $\boldsymbol{S}$. fragilis could be exploiting drift kelp funneled and

387 deposited in the shallow canyon. Ophiuroids and pennatulids were associated with the

388 deep-water habitats (1500-2000 m), likely because of an avoidance of low oxygen.

389 In contrast, some groups were present throughout most of the canyon, although

390 different morphospecies occurred at different depths. For example, of the holothuroid

391 species that were identified, Parastichopus leukothele was present in the shallow

392 transects (200-, 300-, 400-m) and Pannychia moseleyi and Scotoplanes theeli were found

393 in deeper (>800-m) transects, reflecting previously recorded bathymetric patterns (Maluf

394 1987; Blaine 2011). P. leukothele has been found in both soft and hard sediment areas but

395 rarely deeper than $300 \mathrm{~m}$ in Californian waters (Blaine 2011), likely indicating that depth

396 restricts their distribution. Deep-water holothuroids (such as P. moseleyi and S. theeli)

397 have tentacle structures specially designed to exploit deep-water detritus (Carney 2005) 
398 and may be better suited to foraging in deep waters. P. moseleyi has been observed

399 aggregating and feeding on such detrital patches in canyons in California as shallow as

$400300 \mathrm{~m}$ (Vetter \& Dayton 1999). The shift in decapod abundance with increasing depth

401 from two larger species to a smaller one (Family Pandalidae) may reflect a decrease in

402 size associated with a decrease in available energy (Rex et al. 2006) or a response to low-

403 oxygen conditions, discussed below. Actiniaria and asteroids were also present

404 throughout the canyon, but identification at higher taxonomic resolution revealed a

405 species-specific pattern in zonation. Order Actiniaria contains species with many

406 different modes of substrate attachment, on either hard or soft sediments or both

407 (Ammons \& Daly 2008). The transition from pebble-dominated to soft sediments could

408 restrict some of the species from recruiting in deeper waters While present at all depths,

409 few actiniarian species found in this study appear in multiple transects (except Actinange

410 verrillii, Actiniaria sp. 5, and Actiniaria sp. 7) indicating that substrate alone does not

411 regulate distribution, and other factors, such as temperature, food availability,

412 species-specific patterns, or patterns in recruitment may play a role since they may

413 also vary at the different depths in the canyon.

4144.2 Zonation in abundance relative to the $O M Z$

415

416 While statistical analyses did not reveal a significant pattern, the presence of the

$417 \mathrm{OMZ}$ appeared to restrict the distribution and abundance of some taxa. The absence of a

418 significant correlation could be due to the small number of transects (and thus reduced

419 statistical power) in the OMZ. Benthic fauna found within OMZs have been reported as

420 primarily composed of protozoan and metazoan meiofauna, likely because small size

421 allows for a lower oxygen requirement and aerobic adaptations for more effective 
422 oxygen uptake, whereas megafauna are rare or absent (Childress \& Siebel 1998; Levin

423 2003; Callow et al. 2014). In Barkley Canyon, a size-related distribution was observed

424 for decapods. The large species spot prawn Pandalus platyceros - known to only occur in

425 oxic conditions and living as deep as $400 \mathrm{~m}$ (Butler 1964; Matabos et al. 2012) - was

426 absent below $200 \mathrm{~m}$ and replaced by smaller species. Pennatulids, hydrozoans, and

427 echinoids were absent within the OMZ, indicating that these taxa may have a

428 physiological lack of tolerance, or a lower threshold, to oxygen levels below $0.05 \mathrm{ml} \mathrm{L}^{-1}$.

429 Echinoderms were nonetheless reported to be the most tolerant to hypoxic events

430 (Vaquer-Sunyer \& Duarte 2010). However, substrate also changed from pebbles at

431 shallow depths to soft clay-like sediment at the upper boundary of the OMZ (600 m).

432 Although depth and terrain steepness contribute to megafaunal distribution, substrate can 433 be the main regulatory factor in some canyons.

434 Although changes in oxygen and substrate are confounded in Barkley Canyon, it

435 appears that the change in substrate may regulate the abundance of hydrozoans, while

436 low oxygen may limit pennatulids. The same morphospecies of Pennatulacea was found

437 both above and below the $\mathrm{OMZ}$ in pebble-dominated and soft sediment, but not within

438 the OMZ. In contrast, different hydrozoan morphospecies were found above and below

439 the OMZ indicating that either sediment or oxygen may be regulating their patterns in

440 abundance. Duffy et al. (2014) also were unable to disentangle the effects of depth and

441 oxygen on species distribution in submarine canyons in a weak OMZ off the coast of

442 California. Squat lobsters were only found in the shallow, well oxygenated transect (200

$443 \mathrm{~m}$ ), which is consistent with a study in the Gulf of California that found that most Munida

444 species ( 8 of 9 studied) were distributed in shallow waters above the OMZ and 
445 experienced a physiological oxygen threshold at $0.10 \mathrm{ml} \mathrm{L}^{-1}$ (Hendrickx \& Serrano

446 2013). However, Munida quadrispina is also highly tolerant to severe hypoxia (Matabos

447 et al. 2012), indicating that improved species identification could help better understand

448 species distribution.

449 In our study, some taxa were not restricted by low-oxygen conditions, such as

450 gastropods, which were present in the core of the OMZ. Gastropods are known to have a

451 higher tolerance to hypoxic conditions and can capitalize on the organic matter preserved

452 in the low $\mathrm{O}_{2}$ environment (Cowie \& Hedges, 1992; Levin, 2003; Vaquer-Sunyer \&

453 Duarte, 2008). However, even taxa expected to be susceptible to hypoxic conditions

454 (Levin 2003) were present in the OMZ in this study, such as decapods (Family

455 Pandalidae) and echinoderms (asteroidea including Crossaster borealis, Pannychia

456 moseleyi, and actiniaria species).

457 Overall, there was no evidence that megafauna abundance were significantly

458 reduced in the $\mathrm{OMZ}$ in Barkley Canyon. Oxygen may not be the regulating factor in

459 this habitat; rather the increase in habitat heterogeneity or funneled food may allow

460 low-oxygen tolerant taxa to survive in the OMZ. However, further study of this

461 OMZ may provide more information on this OMZ-submarine canyon dynamics.

462 Many studies suggest the presence of "edge effects" as an increase in biomass at

463 the edge of severely hypoxic areas due to combined release of oxygen and a supply of

464 organic material in the sediment (Levin 2003; Levin \& Sibuet 2012). Species in OMZ

465 also benefit from a release in predation (Levin 2003). In our study, edge effects were

466 apparent for ophiuroids with abundance being highest at $1500 \mathrm{~m}$. At that depth, oxygen

467 concentration was above $0.5 \mathrm{ml} \mathrm{L}^{-1}$ and total organic carbon was highest in the canyon 
468 (Neus Campanya I. Llovett unpublished data). The presence of "edge effects" for this

469 taxon is consistent with a study along the California continental margin, where

470 ophiuroids had the highest biomass along the lower OMZ boundary (Thompson et al.

471 1985).

4724.3 Patterns in diversity

473 Globally, diversity exhibits a parabolic shape peaking between 1500 and $2500 \mathrm{~m}$

474 (Menot et al. 2010). Submarine canyons can exhibit higher biodiversity than the

475 continental margin at corresponding depths (Vetter \& Dayton 1999; De Leo et al. 2010;

476 McClain \& Barry 2010; Vetter et al. 2010). However, diversity can be depressed within

477 OMZs along continental margins (Levin 2003; Gooday et al. 2010) .

478 In Barkley Canyon, diversity (measured with indices) and expected richness

479 exhibited a bimodal distribution, with a depressed expected richness within the OMZ, and

480 peaking at 300 and $2000 \mathrm{~m}$. The pattern may reflect the combined effects on diversity of

481 depth (peaking at $2000 \mathrm{~m}$ ) and low oxygen (depressed between 400 and $2000 \mathrm{~m}$ ). De Leo

482 et al. (2016) recorded 46 species of megafauna from video transects on the Northeastern

483 Pacific continental margin over similar depths as in our study, but outside the OMZ

484 (30.8-km transect from 300 to $1300 \mathrm{~m}$ ) compared to 55 species recorded inside the

485 canyon in this study (despite a relatively greater sampling effort in De Leo et al. 2016).

486 This increase in species richness is consistent with the hypothesis that submarine

487 canyons, despite the presence of the OMZ, can exhibit higher megafaunal diversity than

488 similar depths along the continental margin. 
489

490

491

492

493

494

495

496

497

498

499

500

501

502

503

504

505

506

507

508

509

510

511

\subsection{Horizontal patterns in abundance across the canyon}

Because the 1-km transects were done perpendicularly to the canyon axis, the ones at shallow target depths covered a range of geomorphologies, from the relative

\section{flat axis to the steep walls towards the NW and SE boundaries of the canyon.}

Patterns in megafaunal abundance were related to seafloor geomorphology however, these patterns may also be confounded with depth. Nonetheless, poriferans were more abundant on the NW wall rather than on the SE wall of Barkley Canyon, possibly indicating a more suitable habitat with increased bottom current flow or breaking internal waves and the presence of suspended organic material (Klitgaard \& Tendal 2004; Beazley et al. 2015). Canyons have dynamic flows, including upwelling, downwelling, internal tides, and asymmetrical currents that could provide enhanced flow to one side of the canyon or enhanced organic re-suspension (Allen et al. 2001; Allen \& Durrieu de Madron 2009). Similarly, in Whittard Canyon in the NE Atlantic, megafaunal abundance was enhanced on the eastern relative to the western canyon due to environmental heterogeneity (Amaro et al. 2016). In contrast, the higher abundance of

Strongylocentrotus fragilis along the axis than the walls of Barkley Canyon (200-400 m) may indicate an increase in food availability in a depositional region. In Carmel Canyon, along the Californian continental margin, the biomass of detritus kelp was significantly higher along the axis of the canyon than on the canyon walls (Harrold et al. 1998).

\subsection{Species aggregations in response to macrodetritus}

Submarine canyons are conduits for organic detrital material and sediment from the shelf to the deep sea, acting as a food source and causing megafaunal aggregations (Vetter 1994; Harrold et al. 1998; Vetter \& Dayton 1999; Puig et al. 2014). Drift kelp in 
512 Barkley Canyon was surveyed to investigate abundance patterns at fine spatial scales.

513 Opportunistic mobile epifauna such as echinoids, holothuroids, and ophiuroids would be

514 expected to aggregate on food sources. The sea urchin Strongylocentrotus fragilis

515 aggregated on detrital kelp at 200 and $300 \mathrm{~m}$, but not at $1500 \mathrm{~m}$, which falls outside its

516 bathymetric distribution (Schultz 2015). The holothurian Pannychia moseleyi is also

517 known to aggregate on detrital plant material (Vetter \& Dayton 1999), but was not

518 present near the kelp. The holothurians that were present did not aggregate near the kelp

519 and likely do not feed on kelp but on particulate organic carbon. Typically, the deep sea

520 has a low but predictable rate of food supply from sinking surface primary production

521 (Gage \& Tyler 1991) and faunal biomass declines with depth because of this low organic

522 input (Carney 2005; Rex et al. 2006). The presence of organic detritus (either drift kelp or

523 fish falls) provides a food source, in addition to organic material funneled from the

524 shelf, and could explain the increased biomass typically found at fine scales within

525 submarine canyons when compared to similar depths in non-canyon habitats (De

526 Leo et al. 2010; Harrold et al. 1998).

\section{5. Conclusions}

528 In Barkley Canyon, British Columbia, faunal zonation appears to be influenced by

529 the combination of depth, oxygen and substrate. Although total megafaunal abundance

530 did not decrease with oxygen, expected richness and diversity did. Comparisons with

531 patterns from other canyons can be difficult because variability can be high, even

532 between canyons in close proximity or within a single canyon (Huvenne \& Davis 2014;

533 Van Oevelen et al. 2011). Our study only focused on epibenthic megafauna and each

534 transect covered an average surface area of $\sim 120 \mathrm{~m}^{2}$. 
535 Continental margins, such as the Canadian Pacific margin, are facing

536 anthropogenic threats, as human exploitation expands from shallow margins into the deep

537 sea (Ramirez-Llodra et al. 2011; Levin \& Sibuet 2012). In addition, oxygen minimum

538 zones are predicted to increase in size due to increasing sea surface temperature and

539 increased ocean stratification, particularly in the North Pacific Ocean, and could result in

540 a global decrease in diversity (Helly \& Levin 2004; Bograd et al. 2008; Chan et al. 2008;

541 Diaz \& Rosenberg 2008; Falkowski et al. 2011). This study adds insight into species

542 distribution and the possible mechanisms underlying these patterns. Considering the

543 increasing anthropogenic and hypoxic threats and the importance of continental margin

544 and submarine canyons, understanding faunal patterns and ecosystems are essential for

545 the Northeast Pacific margin environmental management.

546 


\section{Acknowledgements}

548

549 We thank Dr. K Juniper, Chief Scientist, and the crews of R/V Falkor and the ROV

550 ROPOS. The study was supported by Schmidt Ocean Institute and Ocean Networks

551 Canada, and an NSERC Discovery Grant to Anna Metaxas. Myriam Lacharité was

552 supported by a Killam Predoctoral Fellowship from Dalhousie University. We also thank

553 an anonymous reviewer for their constructive feedback.

554 
555

556

557

558

559

560

561

562

563

564

565

566

567

568

569

570

571

572

573

574

575

576

577

578

579

580

581

582

583

584

585

586

587

588

589

590

591

592

593

594

595

596

597

598

599

600

References

Allen S.E., Durrieu de Madron X. (2009) A review of the role of submarine canyons in deep-ocean exchange with the shelf. Ocean Science Discussions, 6, 1369-1406.

Allen S.E., Vindeirinho C., Thomson R.E., Foreman M.G., Mackas D.L. (2001) Physical and biological processes over a submarine canyon during an upwelling event. Canadian Journal of Fisheries and Aquatic Sciences, 58, 671-684.

Amaro T., Huvenne V.A.I., Allcock A.L., Aslam T., Davies J.S., Danovaro R., De Stigter H.C., Duineveld G.C.A., Gambi C., Gooday A.J., Gunton L.M., Hall R., Howell K.L., Ingels J., Kiriakoulakis K., Kershaw C.E., Lavaleye M.S.S., Robert K., Stewart H., Van Rooij D.,White M. (2016) Progress in Oceanography The Whittard Canyon - A case study of submarine canyon processes. Progress in Oceanography, 146, 38-57.

Ammons A.W., Daly M. (2008) Distribution, habitat use and ecology of deepwater Anemones (Actiniaria) in the Gulf of Mexico. Deep Sea Research Part II: Topical Studies in Oceanography, 55, 2657-2666.

Beazley L., Kenchington E., Yashayaev I., Murillo F.J. (2015) Drivers of epibenthic megafaunal composition in the sponge grounds of the Sackville Spur, northwest Atlantic. Deep Sea Research Part I: Oceanographic Research Papers, 98, 102-114.

Blaine J.M. (2011) Population dynamics and spatial distribution of two commercially important species of sea cucumber, Parastichopus californicus and Parastichopus leukothele, in deep central California waters. Master's thesis, University of Washington, Seattle.

Bograd S.J., Castro C.G., Di Lorenzo E., Palacios D.M., Bailey H., Gilly W., Chavez F.P. (2008) Oxygen declines and the shoaling of the hypoxic boundary in the California Current. Geophysical Research Letters, 35, 1-6.

Butler T.H. (1964) Growth, Reproduction, and Distribution of Pandalid Shrimps in British Columbia. Journal of the Fisheries Research Board of Canada, 21, 14031452.

Callow R.H.T., Kneller B., Dykstra M., Mcilroy D. (2014) Physical, biological, geochemical, and sedimentological controls on the ichnology of submarine canyon and slope channel systems. Marine and Petroleum Geology, 54, 144-166.

Carney R.S. (2005) Zonation of Deep Biota on Continental Margins. Oceanography and Marine Biology: A Annual Review, 43, 211-278.

Chan F., Barth J.A., Lubchenco J., Kirincich A., Weeks H., Peterson W.T., Menge B.A. (2008). Emergence of anoxia in the California current large marine ecosystem. Science, 319, 920.

Cowie G.L., Hedges J.I. (1992) The role of anoxia in organic matter preservation in coastal sediments: relative stabilities of the major biochemicals under oxic and anoxic depositional conditions. Organic Geochemistry, 19, 229-234.

De Leo F.C., Gauthier M., Nephin J., Mihaly S., Juniper, S.K. (2016) Bottom trawling and oxygen minimum zone influences on continental slope benthic community structure off Vancouver Island (NE Pacific). Deep Sea Research Part II: Topical Studies in Oceanography, In press. 
De Leo F.C., Smith C.R., Rowden A.A., Bowden D.A., Clark M.R. (2010) Submarine canyons: Hotspots of benthic biomass and productivity in the deep sea. Proceedings of the Royal Society B: Biological Sciences, 277, 2783-2792.

Diaz R.J., Rosenberg R. (2008) Spreading dead zones and consequences for marine ecosystems. Science, 321, 926-929.

Duffy G.A., Lundsten L., Kuhnz L.A., Paull C.K. (2014) A comparison of megafaunal communities in five submarine canyons off Southern California, USA. Deep-Sea Research Part II: Topical Studies in Oceanography, 104, 259-266.

Falkowski P.G., Algeo T., Codispoti L., Deutsch C., Emerson S., Hales B., Huey R.B., Jenkins W.J., Kump L.R., Levin L.A., Lyons T.W., Nelson N.B., Schofield O.S., Summons R., Talley L.D., Thomas E., Whitney F., Pilcher, C.B. (2011) Ocean deoxygenation: Past, present, and future. Eos, Transactions American Geophysical Union, 92, 409-410.

Freeland H., Crawford W.R., Thomson, R.E. (1984) Currents along the Pacific coast of Canada. Atmosphere-Ocean, 22, 151-172.

Gage J.D., Tyler P.A. (1991) Deep-sea biology: a natural history of organisms at the deep-sea floor. Cambridge: Cambridge University Press.

Gooday A.J., Bett B.J., Escobar E., Ingole B., Levin L.A., Neira C., Raman A.V., Sellanes J. (2010) Habitat heterogeneity and its influence on benthic biodiversity in oxygen minimum zones. Marine Ecology, 31, 125-147.

Harrold C., Light K., Lisin S. (1998) Organic enrichment of submarine-canyon and continental-shelf benthic communities by macroalgal drift imported from nearshore kelp forests. Limnology and Oceanography, 43, 669-678.

Helly J.J., Levin L.A. (2004) Global distribution of naturally occurring marine hypoxia on continental margins. Deep-Sea Research Part I: Oceanographic Research Papers, 51, 1159-1168.

Hendrickx M.E., Serrano D. (2013) Effects of the oxygen minimum zone on squat lobster distributions in the Gulf of California, Mexico. Central European Journal of Biology, 9, 92-103.

Hurlbert S.H. (1971) The Nonconcept of Species Diversity: A Critique and Alternative Parameters. Ecology, 52, 577-586.

Huvenne V.A.I., Tyler P.A., Masson D.G., Fisher E.H., Hauton C., Bas T.P.L, Wolff G.A. (2011) A Picture on the Wall: Innovative Mapping Reveals Cold- Water Coral Refuge in Submarine Canyon. PLoS ONE, 6, 1-10.

Inman D.L., Nordstrom C.E., Flick R.E. (1976) Currents in Submarine Canyons: An AirSea-Land Interaction. Annual Review of Fluid Mechanics, 8, 275-310.

Juniper S.K., Matabos M., Mihály S., Ajayamohan R.S., Gervais F., Bui A.O.V. (2013) A year in Barkley Canyon: A time-series observatory study of mid-slope benthos and habitat dynamics using the NEPTUNE Canada network. Deep-Sea Research Part II: Topical Studies in Oceanography, 92, 114-123.

Klitgaard A.B., Tendal O.S. (2004) Distribution and species composition of mass occurrences of large-sized sponges in the northeast Atlantic. Progress in Oceanography, 61, 57-98.

Levin L.A. (2003) Oxygen minimum zone benthos: adaptation and community response to hypoxia. Oceanography and Marine Biology: An Annual Review, 41, 1-45. 
647

648

649

650

651

652

653

654

655

656

657

658

659

660

661

662

663

664

665

666

667

668

669

670

671

672

673

674

675

676

677

678

679

680

681

682

683

684

685

686

687

688

689

690

691

692

Levin L.A., Etter R.J., Rex M.A., Gooday A.J., Smith C.R., Pineda J., Stuart C.T., Hessler R.R., Pawson, D. (2001). Environmental Influences on Regional Deep-Sea Species. Annual Review of Ecology and Systematics, 32, 51-93.

Levin L.A., Gage J. (1998) Relationships between oxygen, organic matter and the diversity of bathyal macrofauna. Deep-Sea Research Part II: Topical Studies in Oceanography, 45, 129-163.

Levin L.A., Sibuet M. (2012) Understanding continental margin biodiversity: A new imperative. Annual Review of Marine Science, 4, 79-111.

Maluf L. Y. (1987) Classification and Distribution of the Central Eastern Pacific Echinoderms. Ph.D. thesis, University of Arizona, Flagstaff.

Matabos M., Tunnicliffe V., Juniper S.K., Dean C. (2012) A year in hypoxia: epibenthic community responses to severe oxygen deficit at a subsea observatory in a coastal inlet. PLoS One, 7, e45626.

McClain C.R., Barry J.P. (2010) Habitat heterogeneity, disturbance, and productivity work in concert to regulate biodiversity in deep submarine canyons. Ecological Society of America, 91, 964-976.

Menot L., Sibuet M., Carney R.S., Levin L.A., Rowe G.T., Billett D.S.M.B, Poore G., Kitazato H., Vanreusel A., Galeron J., Lavrado H.P., Sellanes J., Ingole B., Krylova, E. (2010). New Perceptions of Continental Margin Biodiversity. In: McIntyre A.D. (Ed.), Life in the World's Oceans: Diversity, Distribution, and Abundance, WileyBlackwell, Oxford, UK: pp. 79-101.

Pierdomenico M., Martorelli E., Dominguez-Carrió C., Gili J.M., Chiocci F.L. (2016) Seafloor characterization and benthic megafaunal distribution of an active submarine canyon and surrounding sectors: The case of Gioia Canyon (Southern Tyrrhenian Sea). Journal of Marine Systems, 157, 101-117.

Puig P., Palanques A., Martín J. (2014) Contemporary sediment-transport processes in submarine canyons. Annual Review of Marine Science, 6, 53-77.

Ramirez-Llodra E., Tyler P.A., Baker M.C., Bergstad O.A., Clark M.R., Escobar E., Levin L.A., Menot L., Rowden A.A., Smith C.R., van Dover C.L. (2011) Man and the last great wilderness: Human impact on the deep sea. PLoS ONE, 6,e22588.

Reid J.L., Mantyla A.W. (1978) On the mid-depth circulation of the North Pacific Ocean. Journal of Physical Oceanography, 8, 946-951.

Rex M., Etter R.J., Morris J.S., Crouse J., McClain C.R., Johnson N.A., Stuart C.T., Deming J.W., Thies R., Avery, R. (2006) Global bathymetric patterns of standing stock and body size in the deep-sea benthos. Marine Ecology Progress Series, $\mathbf{3 1 7}$, $1-8$.

Sato K., Levin L., Schiff K. (2017) Habitat compression and expansion of sea urchins in response to changing climate condition on the California contienental shelf and slope (1994-2013). Deep Sea Research Part II, 137, 377-389.

Schultz H. (2015) Echinoidea: With Pentameral Symmetry, Handbook of Zoology Vol 1. Hemdingen, Germany: Walter De Gruyter Incorporated.

Smith J.T. (1970) Taxonomy, distribution, and phylogeny of the cymatiid gastropods Argobuccinum, Fusitriton, Mediargo, and Priene. Ithaca, N.Y: Paleontological Research Institution.

Thompson J.B., Mullins H.T., Newton C.R., Vercoutere T.L. (1985) Alternative biofacies model for dysaerobic communities. Lethaia, 18, 167-179. 
693

694

695

696

697

698

699

700

701

702

703

704

705

706

707

708

709

710

711

712

713

714

715

716

717

718

719

720

721

722 van Oevelen D., Soetaert K., Garcia R., de Stigter H.C., Cunha M.R., Pusceddu A., Danovaro R. (2011) Canyon conditions impact carbon flows in food webs of three sections of the Nazaré canyon. Deep Sea Research Part II: Topical Studies in Oceanography, 58, 2461-2476.

Vaquer-Sunyer R., Duarte C.M. (2008) Thresholds of hypoxia for marine biodiversity. Proceedings of the National Academy of Sciences of the United States of America, 105, 15452-15457.

Vaquer-Sunyer R., Duarte C.M. (2010) Sulfide exposure accelerates hypoxia-driven mortalit. Limnology and Oceanography, 55, 1075-1082.

Vetter E.W. (1994) Hotspots of benthic production. Nature. 372, 47

Vetter E.W., Dayton P.K. (1998) Macrofaunal communities within and adjacent to a detritus-rich submarine canyon system. Deep Sea Research Part II: Topical Studies in Oceanography, 45, 25-54.

Vetter E.W., Dayton P.K. (1999) Organic enrichment by macrophyte detritus and abundance patterns of megafaunal population in submarine canyons. Marine Ecology Progress Series, 186, 137-148.

Vetter E.W., Smith C.R., De Leo F.C. (2010) Hawaiian hotspots: Enhanced megafaunal abundance and diversity in submarine canyons on the oceanic islands of Hawaii. Marine Ecology, 31, 183-199.

Vogel S. (1977) Current-induced flow through living sponges in nature. Proceedings of the National Academy of Sciences of the United States of America, 74, 2069-2071.

Whitney F.A., Freeland H.J., Robert M. (2007) Persistently declining oxygen levels in the interior waters of the eastern subarctic Pacific. Progress in Oceanography, 75, 179-199.

Wyrtky K. (1966) Oceanography of the Eastern Equatorial Pacific Ocean. Oceanography and Marine Biology: An Annual Review, 4, 33-68. 
723

724

725

726

727

728

729

730

731

732

733

734

735

736

737

738

739

740

741

742

743

744

745

746

747

748

749

750

751

752

753

754

755

756

757

758

759

760

761

762

763

764

765

766

767

\section{Figure captions}

Figure 1. Bathymetric map of Barkley Canyon a submarine canyon off the western coast of Vancouver Island, British Columbia, Canada. Diamonds indicate the location of 1-km transects along isobaths within the canyon (target depths: 200, 300, 400, 600, 800, 1500, $2000 \mathrm{~m})$.

Figure 2. Oxygen, salinity, and temperature profiles measured during the ROPOS dive to $2000 \mathrm{~m}$ in Barkley Canyon, British Columbia, Canada in September 2013. The red dashed line indicates the threshold oxygen concentration between oxic and Oxygen Minimum Zone conditions $\left(<0.5 \mathrm{ml} \mathrm{L}^{-1}\right.$, Levin 2003).

Figure 3. Substrate at different depths within Barkley Canyon, British Columbia, Canada, in September 2013 ( $A=176 \mathrm{~m}, \mathrm{~B}=213 \mathrm{~m}, \mathrm{C}=321 \mathrm{~m}, \mathrm{D}=578 \mathrm{~m}, \mathrm{E}=768 \mathrm{~m}$, $\mathrm{F}=1489 \mathrm{~m})$. Images $\mathrm{D}$ and $\mathrm{E}$ occur within the $\mathrm{OMZ}$. The scale bar is $10-\mathrm{cm}$.

Figure 4. Mean abundance (logarithmic scale) of the dominant taxonomic groups present at 7 depths in Barkley Canyon, British Columbia, Canada in September 2013. Absence of taxa is indicated in white. Transects at 600 and $800 \mathrm{~m}$ are within the oxygen minimum zone $\left(<0.5 \mathrm{ml} \mathrm{L}^{-1}\right)$.

Figure 5. Redundancy canonical analysis of environmental factors (depth, temperature, substrate, and oxygen concentrations) and megafaunal abundance at the group level. The first axis (RDA 1) accounts for $45.2 \%$ of the total variation in the data.

Figure 6. Abundance (individuals $\mathrm{m}^{-2}$ ) of three taxonomic groups (Porifera, Echinoidea, Decapoda) binned into 50-m distances along 1-km transects at four target depths (200, 300, 400, and $600 \mathrm{~m}$ ) in Barkley Canyon, British Columbia, Canada, in September 2013 (square-root scale shown for Decapoda only). NW and SE, respectively, represent the northwest and southeast walls of the canyon. The total number of individuals sampled at each depth is indicated. Decapoda were composed of three different morphologically different taxa. A second poriferan morphospecies was removed because of low sample size $(n=1)$.

Figure 7. Megafaunal abundance and diversity at 7 transect depths $(200,300,400,600$, 800, 1500, 2000 m) in Barkley Canyon, British Columbia, Canada in September 2013. (A) Megafaunal abundance (B) morphospecies richness, (C) diversity indices, (D) expected morphospecies richness ( \pm standard errors) for 50 and 100 individuals. * Expected richness cannot be estimated for a sample size of 100 individuals since too few individuals were recorded at $400 \mathrm{~m}(\mathrm{n}=86)$ and $800 \mathrm{~m}(\mathrm{n}=51)$.

Figure 8. Abundance (individuals) of Echinoidea, Holothuroidea, and Ophiuroidea present along 40-m cross transects over drift kelp located at the centre of the transect, at 3 depths in Barkley Canyon (200 m, 300 m, and 1500 m). 
2

3

4

5

6

7

8

9

10

11

12

13

14

15

16

17

18

19

20

21

22

23

24

25

26

27

28

29

30

31

32

33

34

35

36

37

38

39

40

41

42

43

44

45

46

47

48

49

50

51

52

53

54

55

56

57

58

59

60

768 Figure 9. Aggregation of the Oregon hairy triton Fusitriton oregonensis on a carcass of 769 an unidentified large fish (surface area $=396.9 \mathrm{~cm}^{2}$ ) at $174 \mathrm{~m}$, in Barkley Canyon. 
Table 1. Data collected over $71-\mathrm{km}$ transects along isobaths in Barkley Canyon, British Columbia, Canada with the ROV ROPOS in September 2013. Target depth and start position for each transect are indicated.

\begin{tabular}{|c|c|c|c|c|c|c|c|c|c|c|}
\hline Dive & $\begin{array}{l}\text { Target } \\
\text { depth } \\
\text { (m) }\end{array}$ & $\begin{array}{c}\text { Date } \\
\text { (YY-MM-DD) }\end{array}$ & $\begin{array}{c}\text { Depth } \\
\text { range (m) }\end{array}$ & $\begin{array}{l}\text { Length } \\
\text { (m) }\end{array}$ & $\begin{array}{c}\text { Average } \\
\text { distance } \\
\text { between } \\
\text { frames (m) } \\
{[ \pm \text { SD] }} \\
\end{array}$ & $\begin{array}{l}\text { \# Total } \\
\text { frames }\end{array}$ & $\begin{array}{l}\text { \# Usable } \\
\text { frames }\end{array}$ & $\begin{array}{c}\text { Total } \\
\text { surface area } \\
\text { surveyed } \\
\left(\mathbf{m}^{2}\right)\end{array}$ & Longitude & Latitude \\
\hline R1654 & 200 & 2013-09-14 & $168-200$ & 992 & $8[ \pm 2]$ & 131 & 125 & 123.9 & $125^{\circ} 53^{\prime} 8^{\prime \prime} \mathrm{W}$ & $48^{\circ} 23^{\prime} 49^{\prime \prime} \mathrm{N}$ \\
\hline R1655 & 300 & 2013-09-15 & $183-306$ & 986 & $7[ \pm 2]$ & 152 & 132 & 134.3 & $125^{\circ} 53^{\prime} 51^{\prime \prime} \mathrm{W}$ & $48^{\circ} 23^{\prime} 46^{\prime \prime} \mathrm{N}$ \\
\hline R1655 & 400 & $2013-09-15$ & $268-394$ & 928 & $8[ \pm 2]$ & 123 & 105 & 105.8 & $125^{\circ} 54^{\prime} 40^{\prime \prime} \mathrm{W}$ & $48^{\circ} 24^{\prime} 16^{\prime \prime} \mathrm{N}$ \\
\hline R1658 & 600 & 2013-09-16 & $497-626$ & 1002 & $7[ \pm 2]$ & 152 & 102 & 92.0 & $125^{\circ} 56^{\prime} 36^{\prime \prime} \mathrm{W}$ & $48^{\circ} 22^{\prime} 46^{\prime \prime} \mathrm{N}$ \\
\hline R1657 & 800 & 2013-09-16 & $635-801$ & 988 & $8[ \pm 5]$ & 142 & 125 & 126.1 & $125^{\circ} 59^{\prime} 7^{\prime \prime} \mathrm{W}$ & $48^{\circ} 20^{\prime} 42^{\prime \prime} \mathrm{N}$ \\
\hline R1656 & 1500 & 2013-09-15 & $1479-1511$ & 1006 & $8[ \pm 2]$ & 136 & 136 & 136.3 & $126^{\circ} 9^{\prime} 47^{\prime \prime} \mathrm{W}$ & $48^{\circ} 15^{\prime} 5^{\prime \prime} \mathrm{N}$ \\
\hline R1653 & 2000 & 2013-09-12 & $1863-2001$ & 1004 & $7[ \pm 2]$ & 135 & 135 & 135.4 & $126^{\circ} 19^{\prime} 35^{\prime \prime} \mathrm{W}$ & $48^{\circ} 7^{\prime} 40^{\prime \prime} \mathrm{N}$ \\
\hline
\end{tabular}


Table 2. Data collected over cross transects in Barkley Canyon opportunistically performed upon encounter with drift kelp. The cross transects were centered over the drift kelp (position at kelp is indicated).

\begin{tabular}{lllllll}
\hline Dive & $\begin{array}{l}\text { Target } \\
\text { depth }(\mathbf{m})\end{array}$ & $\begin{array}{l}\text { Date } \\
\text { (YY-MM-DD) }\end{array}$ & $\begin{array}{l}\text { Kelp } \\
\text { depth }(\mathbf{m})\end{array}$ & $\begin{array}{l}\text { Length of each } \\
\text { segment (m) }\end{array}$ & Kelp Longitude & Kelp Latitude \\
\hline R1654 & 200 & $2013-09-14$ & 169 & 69,86 & $125^{\circ} 53^{\prime} 19^{\prime \prime} \mathrm{W}$ & $48^{\circ} 24^{\prime} 21^{\prime \prime} \mathrm{N}$ \\
R1655 & 300 & $2013-09-15$ & 313 & 44,38 & $125^{\circ} 54^{\prime} 39^{\prime \prime} \mathrm{W}$ & $48^{\circ} 24^{\prime} 15^{\prime \prime} \mathrm{N}$ \\
R1656 & 1500 & $2013-09-15$ & 1509 & 47,39 & $126^{\circ} 10^{\prime} 14^{\prime \prime} \mathrm{W}$ & $48^{\circ} 15^{\prime} 28^{\prime \prime} \mathrm{N}$ \\
\hline
\end{tabular}


Table 3. Qualitative description of the substrate at each 1-km transect in Barkley Canyon.

\begin{tabular}{|c|c|c|}
\hline Dive & Depth (m) & Qualitative description of substrate \\
\hline R1654 & 200 & $\begin{array}{l}\text { Pebbles and shell debris throughout the transect with regular } \\
\text { occurrence of cobbles and large boulders }\end{array}$ \\
\hline R1655 & 300 & $\begin{array}{l}\text { Large cobbles and boulders present on the edges of the transect; } \\
\text { mid transect characterized with soft fine sediment with pebbles } \\
\text { and cobbles }\end{array}$ \\
\hline R1655 & 400 & $\begin{array}{l}\text { Fine sediment with pebbles and occasional cobbles, boulders } \\
\text { rare }\end{array}$ \\
\hline R1658 & 600 & $\begin{array}{l}\text { Soft muddy sediment, high level of bioturbation, and easily } \\
\text { disturbed }\end{array}$ \\
\hline R1657 & 800 & $\begin{array}{l}\text { Soft muddy clay-like sediment, very easily disturbed, very few } \\
\text { pebbles or shell hash }\end{array}$ \\
\hline R1656 & 1500 & Soft muddv sediment with burrows and bioturbation \\
\hline R1653 & 2000 & \\
\hline
\end{tabular}


Table 4. Depth, weight, and size of drift kelp sampled from the cross transects.

\begin{tabular}{lrrrl}
\hline Dive & $\begin{array}{c}\text { Sample depth } \\
(\mathbf{m})\end{array}$ & $\begin{array}{c}\text { Frozen } \\
\text { Weight } \\
(\mathbf{g})\end{array}$ & $\begin{array}{c}\text { Longest blade } \\
\text { length }(\mathbf{c m})\end{array}$ & \multicolumn{1}{c}{ Observations } \\
\hline R1654 & 169 & 84.33 & N/A & Fragmented \\
R1655 & 313 & 1725.1 & 158 & Full kelp with stipe and blades \\
R1656 & 1509 & 29.13 & N/A & Fragmented \\
\hline
\end{tabular}




\section{Appendix A:}

Table A.1. Mean $\left( \pm \mathrm{SD}\right.$, for $\mathrm{n}$ see Table A.2) density (ind. $100 \mathrm{~m}^{-2}$ ) of morphospecies along the $71-\mathrm{km}$ transects in Barkley Canyon. Morphospecies that could be differentiated by morphological features but not be identified are depicted by sp. (species) number.

\begin{tabular}{|c|c|c|c|c|c|c|c|}
\hline \multirow[b]{2}{*}{ Taxa } & \multicolumn{7}{|c|}{ Average Density (ind. $100 \mathrm{~m}^{-2}$ ) } \\
\hline & $200 \mathrm{~m}$ & $300 \mathrm{~m}$ & $400 \mathrm{~m}$ & $600 \mathrm{~m}$ & $800 \mathrm{~m}$ & $1500 \mathrm{~m}$ & $2000 \mathrm{~m}$ \\
\hline \multicolumn{8}{|l|}{ Asteroidea } \\
\hline Orthasterias koehleri & 0.8 & 0.8 & 0.9 & & & & \\
\hline Genus Psuedarchaster & 1.7 & & & & & & \\
\hline Cheiraster dawsoni & & 0.8 & & & & & \\
\hline Pteraster sp. 1 & & 1.5 & & & & & \\
\hline Ctenodiscus sp. & & 0.8 & & 1 & & & 1.5 \\
\hline Genus Henricia & & & 0.9 & & & & \\
\hline Solaster borealis & & & & 1 & 4.8 & & \\
\hline Asteroidea sp. 1 & & & & & 0.8 & & \\
\hline Pteraster sp. 2 & & & & & 0.8 & 0.7 & \\
\hline Genus Hymenodiscus & & & & & & 0.7 & \\
\hline Asteroidea sp. 2 & & & & & & 0.7 & \\
\hline Asteroidea sp. 3 & & & & & & & 3 \\
\hline Asteroidea sp. 4 & & & $\alpha$ & & & & 0.7 \\
\hline \multicolumn{8}{|l|}{ Holothuroidea } \\
\hline Parastichopus leukothele & 2.5 & 2.2 & 3.8 & & & & \\
\hline Pannychia moseleyi & & & & & 1.6 & & \\
\hline Scoloplanes theeli & & & & & & 29.3 & 1.5 \\
\hline Elasipodida sp. 1 & & & & & & & 5.9 \\
\hline \multicolumn{8}{|l|}{ Pennatulacea } \\
\hline Sessiflorae sp. 1 & 1.8 & 0.7 & 1.2 & & & & 48 \\
\hline Sessiflorae sp. 2 & & & & & & 9.5 & \\
\hline \multicolumn{8}{|l|}{ Alyconacea } \\
\hline Alyconacea sp. 1 & & & & & & & 5.9 \\
\hline Alyconacea sp. 2 & & & & & & & 3 \\
\hline \multicolumn{8}{|l|}{ Crinoidea } \\
\hline Comatulida sp. 1 & & 3.7 & 1.9 & 4 & 3.2 & & \\
\hline \multicolumn{8}{|l|}{ Porifera } \\
\hline Porifera sp. 1 & 7.5 & 6 & 54.8 & 89.9 & 0.8 & & \\
\hline Porifera sp. 2 & 0.8 & & & & & & \\
\hline \multicolumn{8}{|l|}{ Echinoidea } \\
\hline Strongylocentrus fragilis & 36.3 & 27.2 & 13.3 & & & & \\
\hline \multicolumn{8}{|l|}{ Gastropoda } \\
\hline Fusitriton oregonensis & 2.4 & 1.5 & & 18 & 3.2 & & \\
\hline
\end{tabular}




\begin{tabular}{|c|c|c|c|c|c|c|c|}
\hline \multicolumn{8}{|l|}{ Decapoda } \\
\hline Munida sp. & 347.4 & 16 & & & & & \\
\hline Pandalus platyceros & 1.7 & & & & & & \\
\hline Family Pandalidae & & 4.7 & & 37.6 & 22.2 & 4.4 & 5.9 \\
\hline \multicolumn{8}{|l|}{ Hydrozoa } \\
\hline Hydrozoa sp. 1 & & 26.8 & 1.9 & & & & \\
\hline Hydrozoa sp. 2 & & & & & & & 0.7 \\
\hline \multicolumn{8}{|l|}{ Ophiuroidea } \\
\hline Ophiurida sp. 1 & & & 0.9 & 6.1 & & & \\
\hline Asteronyx sp. & & & & & & 9.5 & \\
\hline Ophiurida sp. 2 & & & & & & 295.7 & 48.8 \\
\hline Ophiurida sp. 3 & & & & & & & 3 \\
\hline \multicolumn{8}{|l|}{ Actiniaria } \\
\hline Actiniaria sp. 1 & & 3 & & & & & \\
\hline Actiniaria sp. 2 & & 1.5 & & & & & \\
\hline Actiniaria sp. 3 & & 3.8 & & & & & \\
\hline Actiniaria sp. 4 & & & 1.9 & & & & \\
\hline Actiniaria sp. 5 & & & 1 & & & & 3 \\
\hline Actinauge verrillii & & & & 4.9 & & 1.5 & \\
\hline Actiniaria sp. 6 & & & & 1.1 & & & \\
\hline Actiniaria sp. 7 & & & & 28 & & & 0.7 \\
\hline Actiniaria sp. 8 & & & & 1.2 & & & \\
\hline Actiniaria sp. 9 & & & & & 1.6 & & \\
\hline Actiniaria sp. 10 & & & & & & 2.2 & \\
\hline Actiniaria sp. 11 & & & & & & 1.5 & \\
\hline Actiniaria sp. 12 & & & & & & 7.3 & \\
\hline Actiniaria sp. 13 & & & & & & & 0.7 \\
\hline Actiniaria sp. 14 & & & & & & & 3.7 \\
\hline
\end{tabular}


Table A.2. Standard deviation of mean density (ind. $100 \mathrm{~m}^{-2}$ ) of morphospecies along the 7 1-km transects in Barkley Canyon. Morphospecies that could be differentiated by morphological features but not be identified are depicted by sp. (species) number.

\begin{tabular}{|c|c|c|c|c|c|c|c|}
\hline \multirow[b]{2}{*}{ Taxa } & \multicolumn{7}{|c|}{ Standard Deviation (ind. $100 \mathrm{~m}^{-2}$ ) } \\
\hline & $200 \mathrm{~m}$ & $300 \mathrm{~m}$ & $400 \mathrm{~m}$ & $600 \mathrm{~m}$ & $800 \mathrm{~m}$ & $1500 \mathrm{~m}$ & $2000 \mathrm{~m}$ \\
\hline \multicolumn{8}{|l|}{ Asteroidea } \\
\hline Orthasterias koehleri & 8.9 & 8.7 & 9.7 & & & & \\
\hline Genus Psuedarchaster & 13.8 & & & & & & \\
\hline Cheiraster dawsoni & & 8.7 & & & & & \\
\hline Pteraster sp. 1 & & 8.7 & & & & & \\
\hline Ctenodiscus sp. & & 8.7 & & 1.3 & & & 12.1 \\
\hline Genus Henricia & & & 9.7 & & & & \\
\hline Crossaster borealis & & & & 1.3 & 25 & & \\
\hline Asteroidea sp. 1 & & & & & 8.8 & & \\
\hline Pteraster sp. 2 & & & & & 8.9 & 8.5 & \\
\hline Genus Hymenodiscus & & & & & & 8.6 & \\
\hline Asteroidea sp. 2 & & & & & & 8.6 & \\
\hline Asteroidea sp. 3 & & & & & & & 12.1 \\
\hline Asteroidea sp. 4 & & & & & & & 8.6 \\
\hline \multicolumn{8}{|l|}{ Holothuroidea } \\
\hline Parastichopus leukothele & 16.2 & 14.8 & 19.1 & & & & \\
\hline Pannychia moseleyi & & & & & 12.5 & & \\
\hline Scoloplanes theeli & & & & & & 62.1 & 12.1 \\
\hline Elasipodida sp. 1 & & & & & & & 23.6 \\
\hline \multicolumn{8}{|l|}{ Pennatulacea } \\
\hline Sessiflorae sp. 1 & 14.5 & 8.6 & 12.9 & & & & 76.9 \\
\hline Sessiflorae sp. 2 & & & & & & 31.9 & \\
\hline
\end{tabular}

Alyconacea

Alyconacea sp. 1

Alyconacea sp. 2

\section{Crinoidea}

Comatulida sp. 1

$22.6 \quad 13.7 \quad 24.1 \quad 28.3$

\begin{tabular}{lrrrrr}
\hline Porifera & & & & & \\
Porifera sp. 1 & 137.9 & 15.8 & 129.3 & 389.5 & 8.9 \\
Porifera sp. 2 & 9.5 & & & & \\
\hline
\end{tabular}

\section{Echinoidea}

$\begin{array}{llll}\text { Strongylocentrus fragilis } \quad 93.1 & 68.7 & 5.1\end{array}$

\section{Gastropoda}

Fusitriton oregonensis

$15.3 \quad 12.1$

51.9

17.6

Decapoda

Munida sp.

$624 \quad 83.6$


Pandalus platyceros $\quad 13.8$

Family Pandalidae

4.6

$81.7 \quad 53.4$

2.6

23.6

Hydrozoa

Hydrozoa sp. 1

$134.5 \quad 13.7$

Hydrozoa sp. 2

8.6

Ophiuroidea

Ophiurida sp. 1

Asteronyx sp.

Ophiurida sp. 2

36.2

Ophiurida sp. 3

242.5

72

\section{Actiniaria}

$9.7 \quad 52.3$

Actiniaria sp. 1

Actiniaria sp. 2

Actiniaria sp. 3

Actiniaria sp. 4

Actiniaria sp. 5

Actinauge verrillii

Actiniaria sp. 6

Actiniaria sp. 7

Actiniaria sp. 8

Actiniaria sp. 9

21.2

12.2

19.1

Actiniaria sp. 10

Actiniaria sp. 11

Actiniaria sp. 12

Actiniaria sp. 13

Actiniaria sp. 14

\section{7}

9.7

25.8

11.1

73.5

8.6

11.7

12.6

25.7

12

28.8 


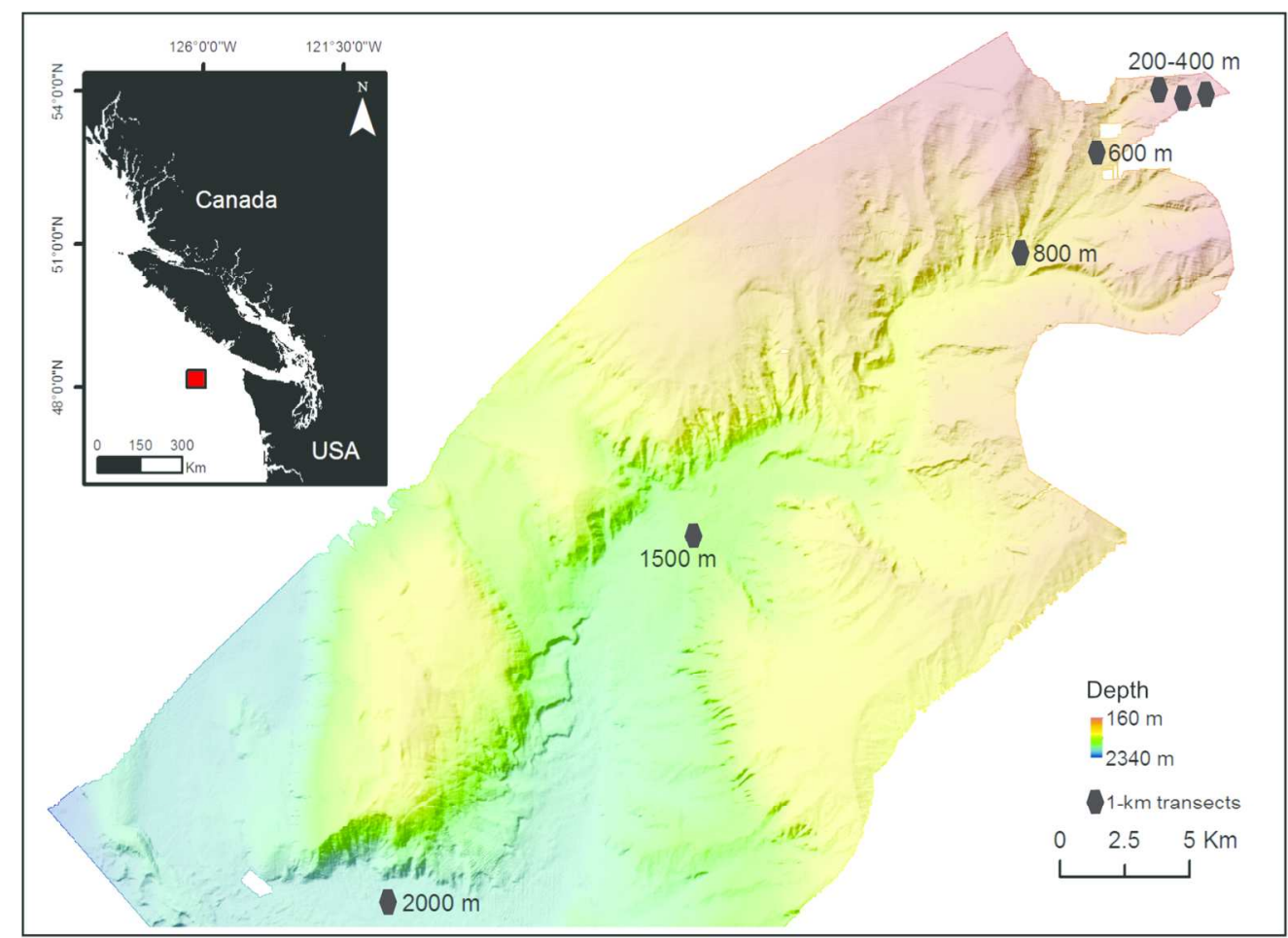

Bathymetric map of Barkley Canyon a submarine canyon off the western coast of Vancouver Island, British Columbia, Canada. Diamonds indicate the location of 1-km transects along isobaths within the canyon (target depths: 200, 300, 400, 600, 800, 1500, $2000 \mathrm{~m}$ ).

\section{$150 \times 110 \mathrm{~mm}(300 \times 300 \mathrm{DPI})$}




\section{Temperature $\left({ }^{\circ} \mathrm{C}\right)$}

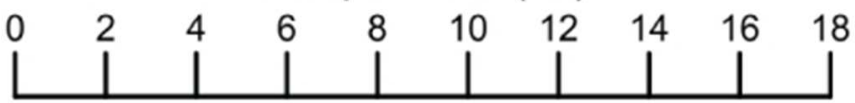

\section{Salinity}
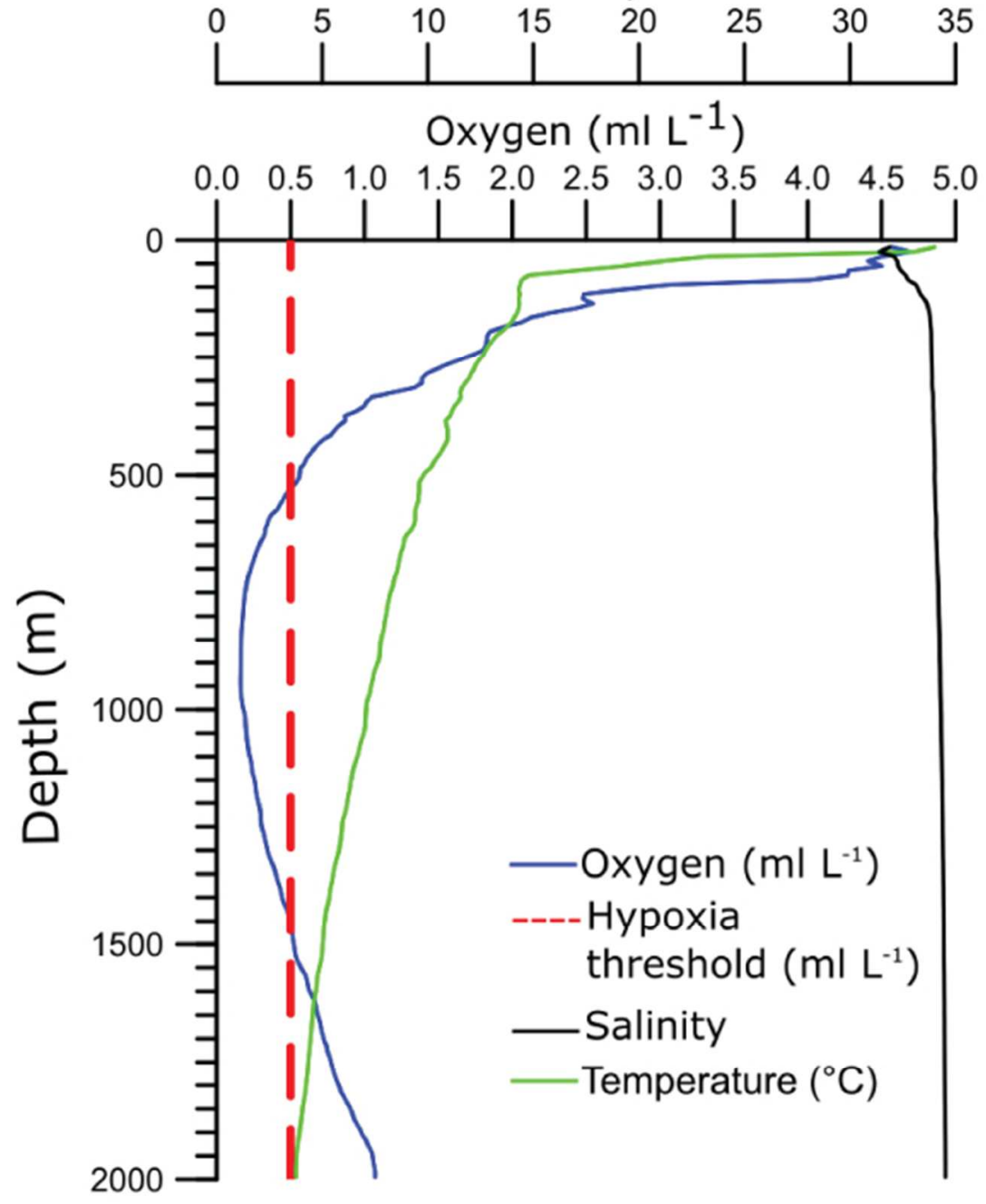

Oxygen, salinity, and temperature profiles measured during the ROPOS dive to $2000 \mathrm{~m}$ in Barkley Canyon, British Columbia, Canada in September 2013. The red dashed line indicates the threshold oxygen concentration between oxic and Oxygen Minimum Zone conditions ( $<0.5 \mathrm{ml} \mathrm{L}^{-1}$, Levin 2003). 

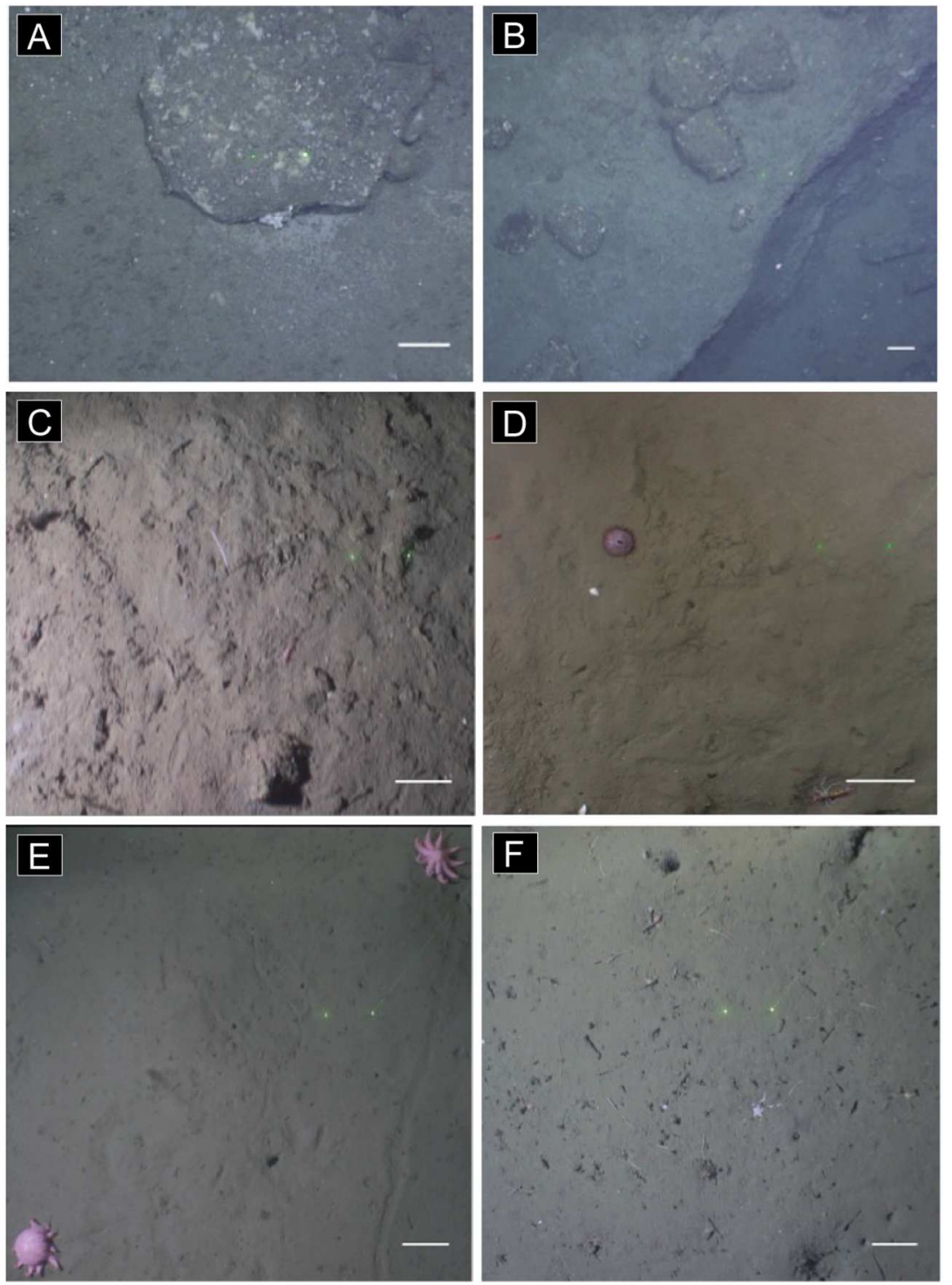

Substrate at different depths within Barkley Canyon, British Columbia, Canada, in September 2013 ( $A=176$ $\mathrm{m}, \mathrm{B}=213 \mathrm{~m}, \mathrm{C}=321 \mathrm{~m}, \mathrm{D}=578 \mathrm{~m}, \mathrm{E}=768 \mathrm{~m}, \mathrm{~F}=1489 \mathrm{~m}$ ). Images $\mathrm{D}$ and $\mathrm{E}$ occur within the OMZ. The scale bar is $10-\mathrm{cm}$.

$112 \times 148 \mathrm{~mm}(300 \times 300$ DPI $)$ 


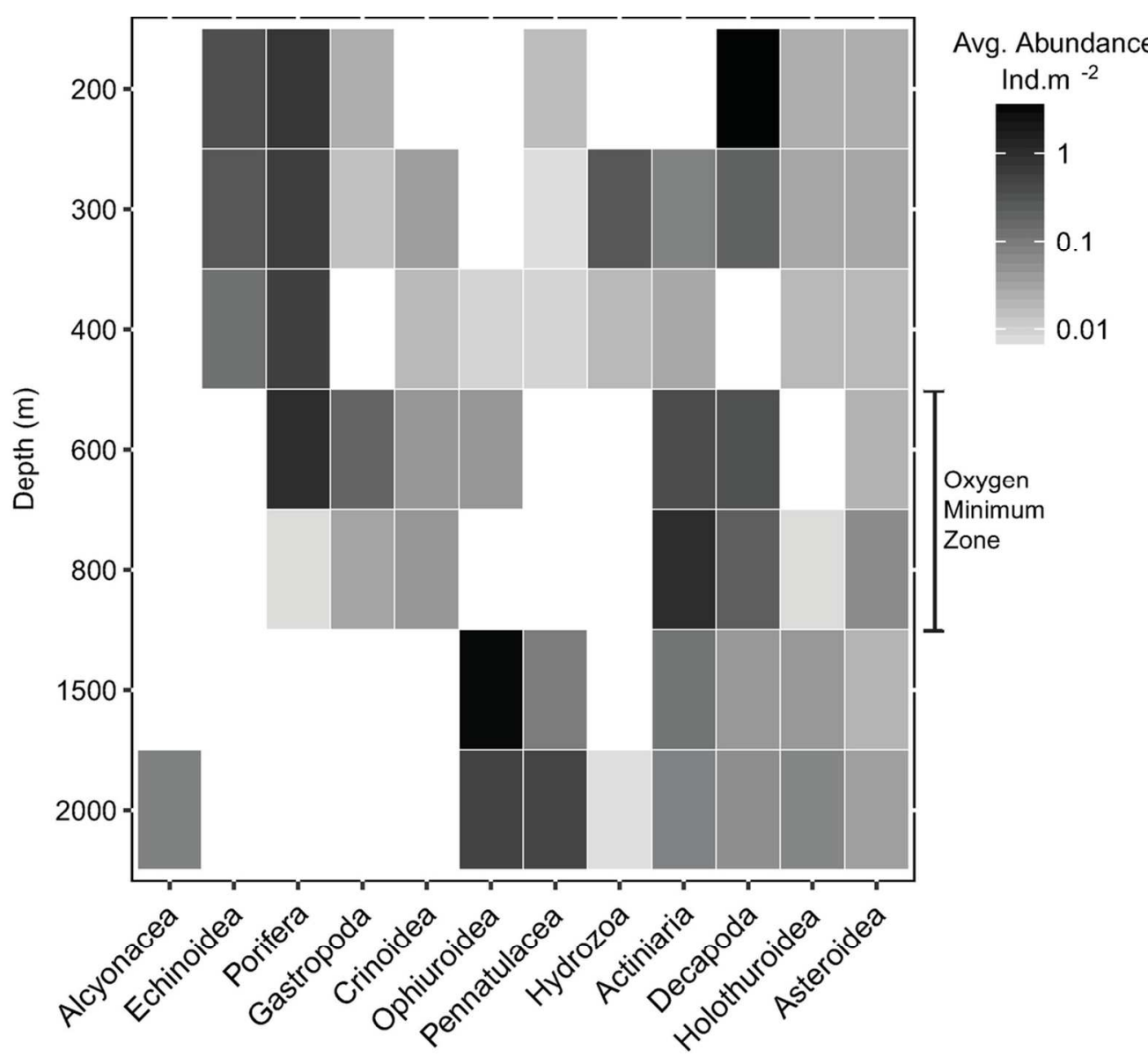

Mean abundance (logarithmic scale) of the dominant taxonomic groups present at 7 depths in Barkley Canyon, British Columbia, Canada in September 2013. Absence of taxa is indicated in white. Transects at 600 and $800 \mathrm{~m}$ are within the oxygen minimum zone $\left(<0.5 \mathrm{ml} \mathrm{L}^{-1}\right)$.

$$
102 \times 92 \mathrm{~mm}(300 \times 300 \mathrm{DPI})
$$


Redundancy canonical analysis of environmental factors (depth, temperature, substrate, and oxygen concentrations) and megafaunal abundance at the group level. The first axis (RDA 1 ) accounts for $45.2 \%$ of the total variation in the data.

\section{$92 \times 47 \mathrm{~mm}(300 \times 300 \mathrm{DPI})$}



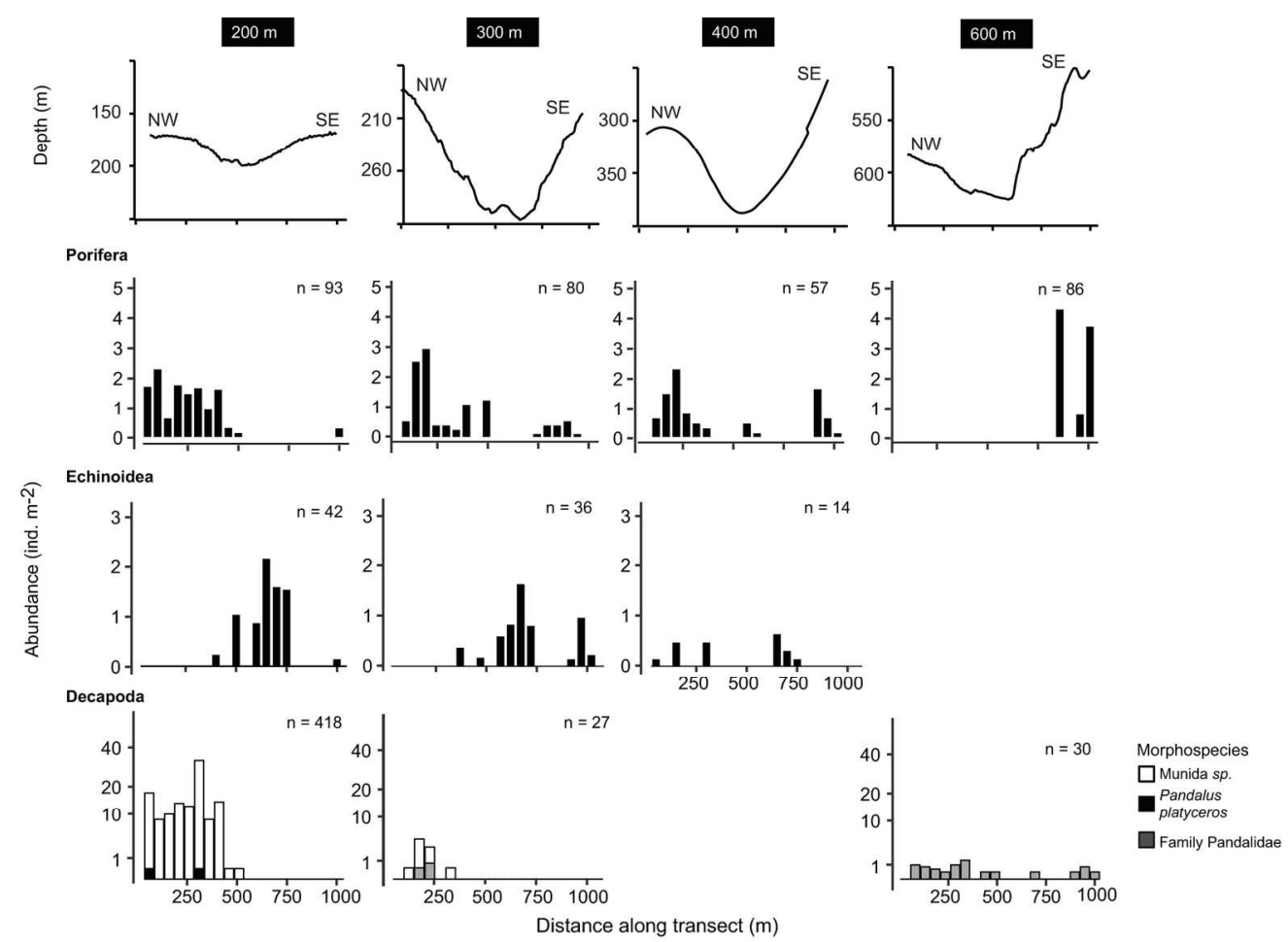

Abundance (individuals $\mathrm{m}^{-2}$ ) of three taxonomic groups (Porifera, Echinoidea, Decapoda) binned into 50-m distances along 1-km transects at four target depths (200,300,400, and $600 \mathrm{~m}$ ) in Barkley Canyon, British Columbia, Canada, in September 2013 (square-root scale shown for Decapoda only). NW and SE, respectively, represent the northwest and southeast walls of the canyon. The total number of individuals sampled at each depth is indicated. Decapoda were composed of three different morphologically different taxa. A second poriferan morphospecies was removed because of low sample size $(n=1)$.

$$
160 \times 116 \mathrm{~mm} \text { ( } 300 \times 300 \mathrm{DPI})
$$



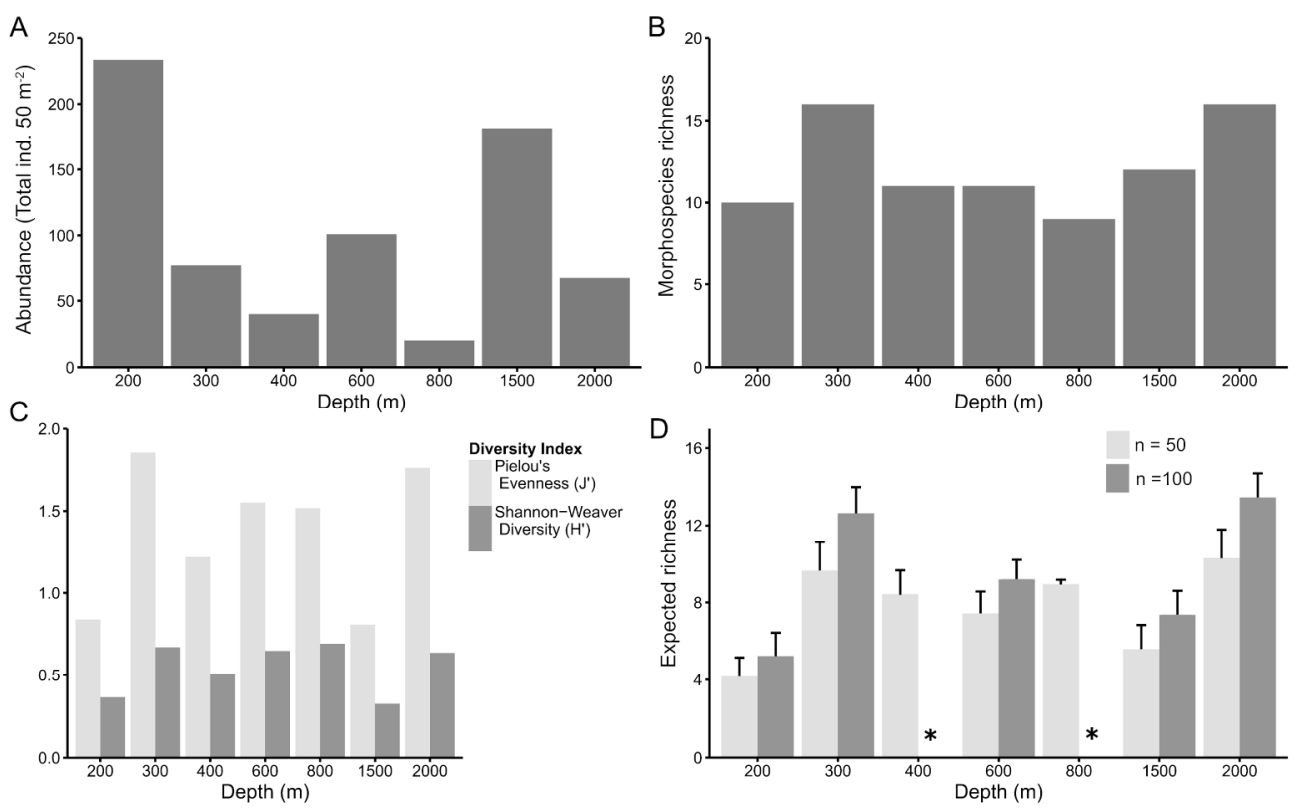

Megafaunal abundance and diversity at 7 transect depths $(200,300,400,600,800,1500,2000 \mathrm{~m})$ in

Barkley Canyon, British Columbia, Canada in September 2013. (A) Megafaunal abundance (B) morphospecies richness, $(C)$ diversity indices, $(D)$ expected morphospecies richness ( \pm standard errors) for 50 and 100 individuals.

* Expected richness cannot be estimated for a sample size of 100 individuals since too few individuals were recorded at $400 \mathrm{~m}(\mathrm{n}=86)$ and $800 \mathrm{~m}(\mathrm{n}=51)$.

$199 \times 122 \mathrm{~mm}(300 \times 300$ DPI $)$ 

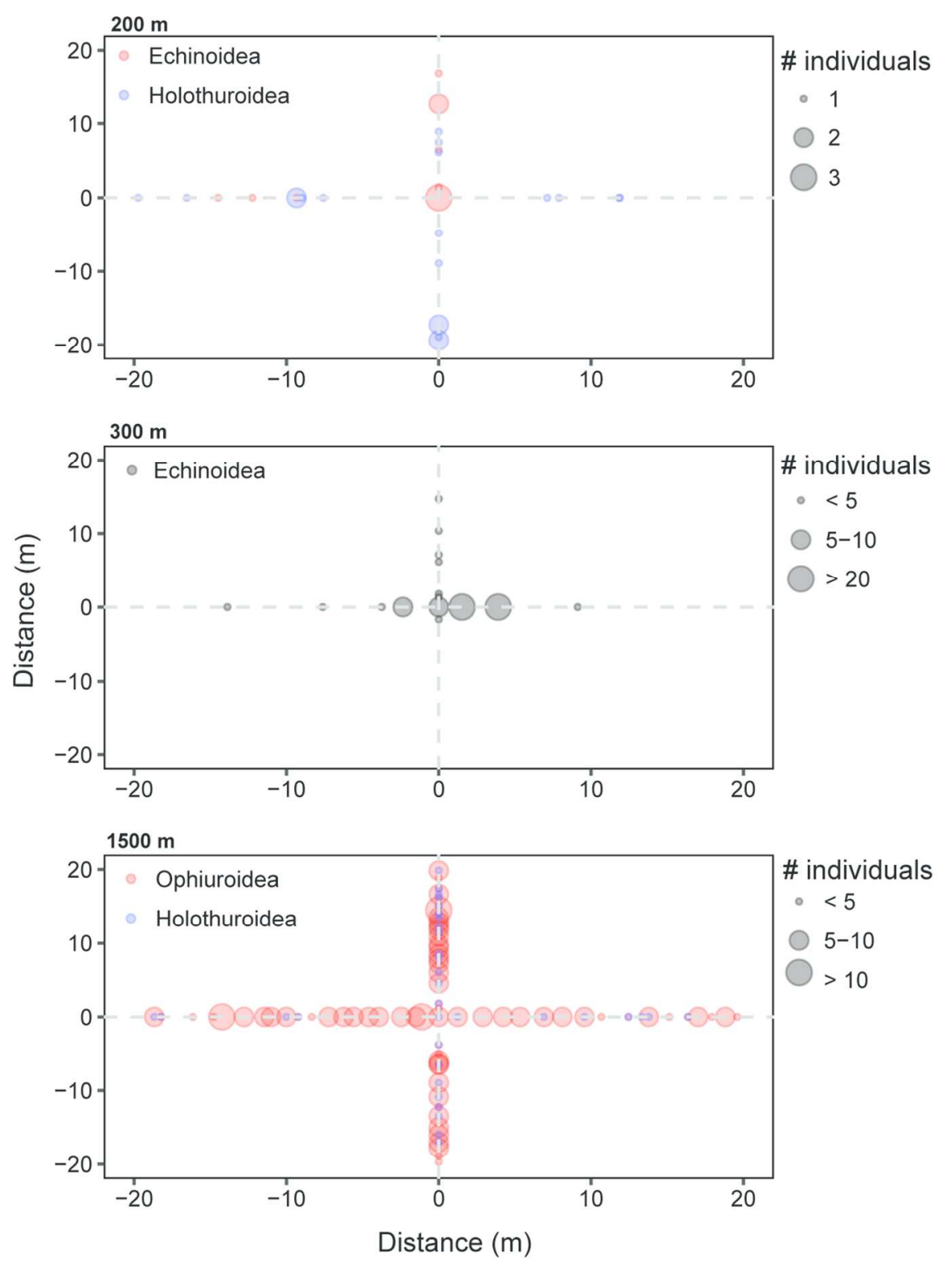

Abundance (individuals) of Echinoidea, Holothuroidea, and Ophiuroidea present along 40-m cross transects over drift kelp located at the centre of the transect, at 3 depths in Barkley Canyon (200 m, 300 m, and 1500 $\mathrm{m})$.

\section{$107 \times 143 \mathrm{~mm}(300 \times 300$ DPI $)$}




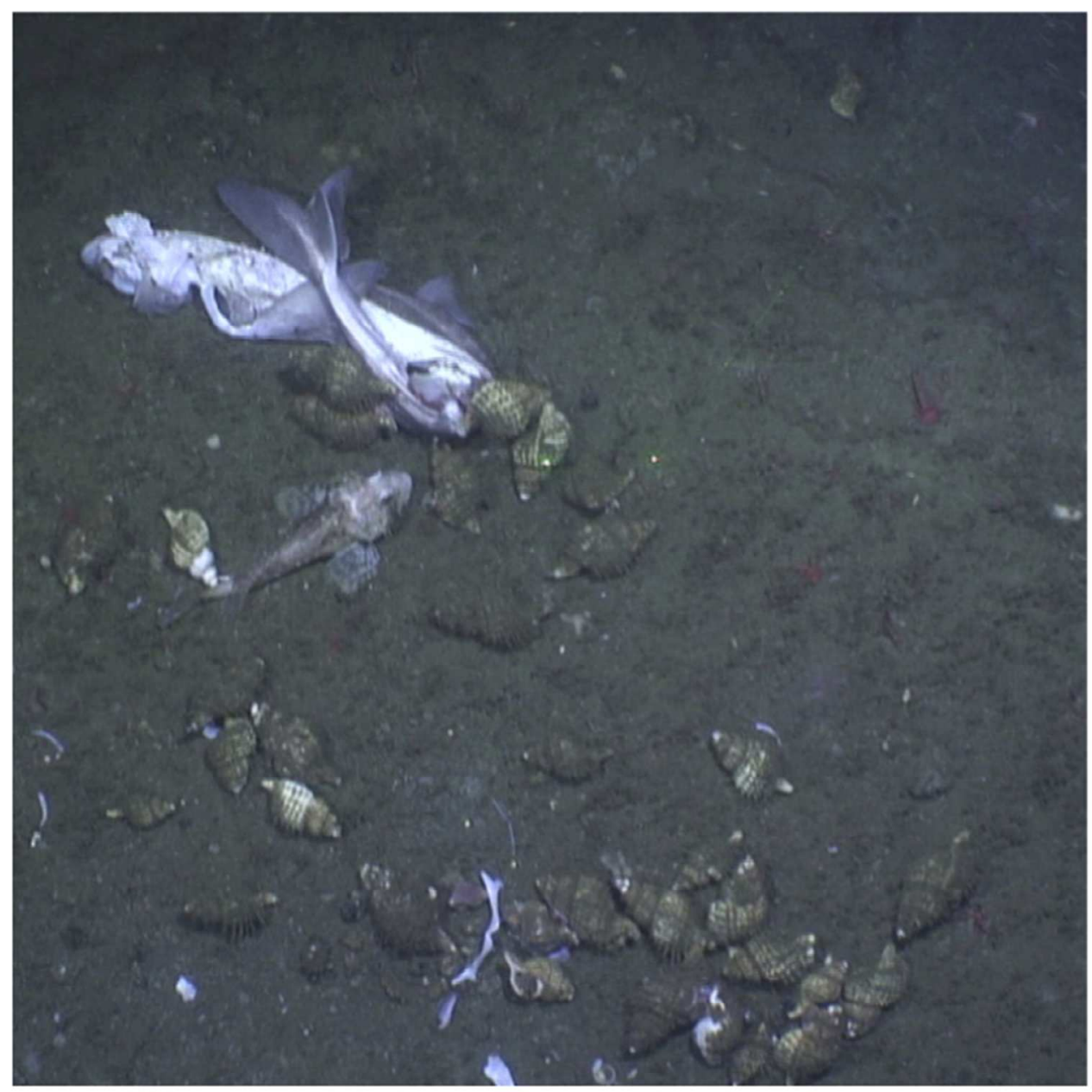

Aggregation of the Oregon hairy triton Fusitriton oregonensis on a carcass of an unidentified large fish (surface area $=396.9 \mathrm{~cm}^{2}$ ) at $174 \mathrm{~m}$, in Barkley Canyon.

$62 \times 62 \mathrm{~mm}(300 \times 300$ DPI $)$ 